\title{
The economics of protected areas - a European perspective
}

\begin{abstract}
This review article argues that the economic consequences of protected areas (PA) represent a growing field of research for economic geographers, which is related to the rising share of land area covered by PA in recent decades. In a theoretical section concepts and ideas of the economics of PA like the public good character of PA benefits or the total economic value concept are presented. The specific characteristics of European PA situated in cultural landscapes strongly shaped by human land use require a comprehensive overview of existing economic valuation studies. Their achievements and gaps are shown and discussed taking the German-speaking countries as an example.
\end{abstract}

Keywords: protected areas, economic valuation, economic impact, Europe, national parks, biosphere reserves, (regional) nature parks

\section{Introduction}

The economic consequences of protected areas (PA) constitute a research field of growing importance for economic geography. Nowadays PA are among the most important land use categories in terms of global area size. In 2011, more than 157000 PA covered about $24.2 \mathrm{~m} \mathrm{~km}^{2}$ or $16.2 \%$ of the global land surface or $4.8 \%$ of the globe (WDPA 2012). Depending on the rigor of their management guidelines PA restrict the conventional land use of agriculture, forestry or mining but also the development of infrastructure-based tourism. This causes opportunity costs for different actors on varying spatial levels. However, at the same time PA also provide benefits for the society. These benefits lead to direct and tangible payment flows into PA regions, which are straightforward to quantify and monetarize. They occur in the form of state funding for PA management or investments in visitor facilities and stem particularly from the expenditure by nature-based tourists (DixON/SHERMAN 1990, 1991).

Additionally PA generate a number of intangible benefits for the society as whole in the form of public goods like the preservation of ecosystem services, recreational values or different non-use values which are difficult to value in monetary terms. Nevertheless, the neglect of these less tangible values results in irrational decisions about PA and therefore leads to a misallocation of economic resources. However, as those ac- tors who bear the opportunity costs of PA do not consistently profit from PA benefits (if at all), economically rooted land use conflicts about the designation of PA arise as a result. Taking these valuation tasks into account, the issues of the (spatial) distribution of costs and benefits intermingled with questions of conflict, power and resources including different economic sectors, branches, actors and businesses on different spatial scales in differing stages of socio-economic development, it is indisputable that the economics of PA represents a topic of special relevance for economic geography.

This special issue aims to present the state-ofthe-art of research on the economics of protected areas (PA) in Europe where such an overview is not available so far. Contrary to the often worldwide renowned PA on other continents with their long tradition and their emblematic species, European PA are confronted with partly strongly hemerobic cultural landscapes which have mostly been intensively used for centuries. Additionally the comparative youth of European PA results in their far smaller popularity compared to e. g. Yosemite, the Serengeti or the Great Barrier Reef. Furthermore the opportunity costs of PA in Europe, which is densely populated in global comparison, differ from other regions of the world as for instance the economic importance of the primary sector is mostly marginal compared to developing countries. Additionally, the prevailing free access policy of not charging entrance fees to PA poses enormous prob- 
lems for visitor monitoring and assessments of the economic impact of PA tourism as there are mostly no reliable visitor data available for European PA.

The contributions to this issue reflect Europe's geographical variability (Portugal, France, Sweden, the Alps, the German-speaking countries, Russia) and they deal as comprehensively as possible with all aspects of the topic, both considering the subject orientations and different PA and IUCN (International Union for Conservation of Nature) categories like national parks, biosphere reserves or (regional) nature parks and their implications for economic geography.

The purposes of this review article are (1) to present protected areas as a relevant topic for economic geography, (2) to explain existing valuation concepts and ideas as well as (3) to provide the state of the art of economic valuation of protected areas in German-speaking countries. Thus, while the second section approaches the subject from a conceptual perspective, the third section gives an overview of empirical research and its results. In the last section the themes and structure of this special issue are outlined.

\section{Economics and economic geography of protected areas: conceptual approaches}

Given the fact that more than $16 \%$ of the global land surface is under legal protection - in Germany protected areas (PA) in total cover nearly $30 \%$ of the land surface (BfN 2012) with strict PA categories like national parks and nature protection areas totaling 3.6\% (BfN 2014) - it is surprising that there has not been a greater focus of economic geography on PA. A fortiori, as the non-use of land paradoxically constitutes an increasingly important land-use category globally and nation-wide. As the sub-discipline of the economic geography of PA has not been established so far, the issues of economic valuation of PA have been largely dealt with by resource or environmental economists while social geographers and landscape ecologists have often focused on the sociocultural aspects of PA like acceptance or conflict issues (for Germany see e.g. RENTSCH 1988; Job 1996; Stoll 1999; BeCKMANN 2003; LIEBECKE et al. 2009; vON RUSCHKOWSKI 2010; MÜLLER 2011). The lack of interest of mainstream economic geography in PA research is remarkable, as PA may lead to enormous economic consequences for the surrounding areas primarily in terms of costs, but also in terms of benefits (WOLTERING 2012). Furthermore, as argued by WELLS as early as 1992, these economic consequences, be they positive or negative, vary considerably for different spatial scales/levels - without any doubt, the analysis of economic activities on different spatial scales is normally said to be at the heart of economic geography (BATHELT/GLÜCKLER 2012). We argue that PA should constitute an important field of research for economic geography also for the following reasons (JoB et al. 2013b):

- The economic geography perspective of PA matters because land use decisions are economic decisions in the first place. Hence, it makes sense also to analyze the economic viability of PA, as land use options are of growing importance in order to decide rationally.

- Adversaries and critics of PA often use economic arguments against PA to demonstrate their alleged inefficiency, the supposed waste of worthy resources or the hampering of economic development. A sound economic valuation of PA can beat those people at their own game because most of these standard arguments against PA can be countered by empirical studies.

- From a nature conservation perspective, the acceptance of a PA and its conservation measures as well as the attitudes of locals, politicians in charge and the general public towards these issues are crucial for successful conservation policies. Under the "traditional paradigm" (STERN 2008) it is argued that a positive economic valuation of PA improves acceptance and attitudes towards PA among the stakeholders mentioned. This means that economic valuation of PA serves as an argument in favor of nature conservation, which is easier to understand and to follow for most people than e. g. the rather abstract biodiversity indices.

A protected area is generally understood as "a clearly defined geographical space, recognised, dedicated and managed, through legal or other effective means, to achieve the long-term conservation of nature with associated ecosystem services and cultural values. ... In the context of this definition conservation refers to the insitu maintenance of ecosystems and natural and semi-natural habitats and of viable populations of species in their natural surroundings ..." (DUDLEY/IUCN 2008，8f.). The bottom line 
of this understanding is that PA, especially the stricter categories like national parks - or the core zones of biosphere reserves (BR) - aiming at ecosystem dynamics unspoiled by humans, are contradictory to nearly all economic activities of mankind, be they agriculture, fishing, forestry, mining, production units and also settlements. Also the PA categories focusing on the protection of cultural landscapes like the outer zones of BR and (regional) nature parks most often put use restrictions on economic activities promoting sustainable land use which should by definition exclude intensification.

That means, that PA - if managed according to their objectives and aims of course - hinder the free usage of productive factors in market economies (Rommel 1998, 85, $92 \mathrm{f}$.): Land or natural resources cannot be exploited, extracted or harvested at all or only under certain limitations; the capital stock already invested in PA loses its productivity and turns into sunk costs - due to the mobility of capital, the imposed restrictions by PA and potential investment alternatives, the PA region might lose its attractivity for further investments; labor is not as mobile as capital but not as spatially fixed as land or natural resources. However, due to a lack of job alternatives for people of a specific qualification level in the PA region a PA designation might restrict incomeearning possibilities for the natives of their surroundings unless people are willing and able to move or to commute to jobs outside the PA region. This underlines the fact that per definition strict nature conservation without any doubt leads to economic restrictions.

Therefore the following questions arise: What is the extent and impact of these restrictions? Who bears the costs, where do they occur spatially and, most importantly, do the economic benefits of PA partly or completely compensate or even surpass these costs?

Under a traditional neoclassical paradigm not taking public goods or even ecosystem services into account these economic restrictions creating considerable opportunity costs have dominated the economic debate about PA. This is no longer the case as the pioneers in environmental and/ or ecological economics like WEISBROD (1964), KRUTILLA/FISHER (1975) and others have introduced important ideas since the 1960s: First, economic development (as opposed to nature protection) also causes opportunity costs (e.g. the recreational value of a valley transformed for hydro-power by dam construction and flooding). Second, economic benefits of PA in the form of non-market values (e.g. recreational value, indirect use values like biodiversity protection, air purification or non-use values like existence and bequest value) have been neglected although they could add up to considerable amounts (BROOKSHIRE et al. 1983, WALSH et al. 1984). Thus, PA have to be regarded as environmental goods consisting of a bundle of private and public goods (see Tab. 1). This means that an economic valuation of PA without incorporating their public good components would be misleading and biased to the disadvantage of PA and nature protection (BALMFORD et al. 2002).

The following conceptual framework (Fig. 1) differentiates between the cost and benefit categories of PA on the national and regional economic level, as well as their measurability - the darker a category is shown, the harder it is to measure it in monetary terms.

DiXon/Sherman $(1990,1991)$ distinguish three main categories of costs of PA, namely direct costs (DC), consisting of expenditures for equipment, maintenance and management of PA, indirect costs (IDC), made up of damages outside PA caused by wildlife from the parks, and opportunity costs (OC), defined as forgone income from alternative land use possibilities, for instance forestry, mining or infrastructure-based tourism development like ski resorts.

The benefits of PA can be categorized using the concept of total economic value (TEV) formulated for the first time by RANDALL/Stoll (1983), which can be understood as a comprehensive analytical framework for the economic valuation of nature and landscapes. The basic idea is that TEV consists of several parts respectively that a natural good may be economically used several times simultaneously (RoTHGANG 1997, 189; MEYerhoff 1999, 22). This is why TuRNER et al. $(2003,494)$ see TEV as a taxonomy of environmental values, which can also be regarded as a holistic conception of value (WCPA 1998, 13). Consequently, for BARBIER et al. $(1997,14)$ the main function of the TEV concept is the differentiation and grouping of the values of natural resources. PASCUAL et al. $(2010,188)$ define TEV more generally as the total values of all services generated by the natural capital now as well as in future. In this way TEV encompasses all (non-)use components of ecosystem services measured in monetary units. 
Tab. 1: Public good characteristics of protected area benefits

\begin{tabular}{|c|c|c|c|c|c|}
\hline & & $\begin{array}{l}\text { Joint con- } \\
\text { sumability }\end{array}$ & $\begin{array}{c}\text { Non- } \\
\text { excludable }\end{array}$ & Nonrival & Type of good \\
\hline \multirow{5}{*}{ 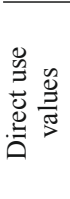 } & Economic impact of park expenditures/investments & no & no & no & Private good \\
\hline & Productive, consumptive and extractive land use & no & no & no & Private good \\
\hline & Economic impact of tourism & no & no & no & Private good \\
\hline & Experience value & yes & yes, partly & yes, partly & PG with cap. limit \\
\hline & Intangible direct use values & yes & no & yes, partly & PG with cap. limit \\
\hline \multirow{7}{*}{ 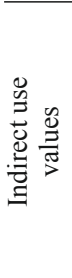 } & Genetic resources / biodiversity & yes & yes, partly & yes & PG with cap. limit \\
\hline & Flood prevention & yes & yes & yes & Pure public good \\
\hline & Water resources & yes & yes & yes & Pure public good \\
\hline & Air purification & yes & yes & yes & Pure public good \\
\hline & Soil formation & yes & yes & yes & Pure public good \\
\hline & Climate regulation & yes & yes & yes & Pure public good \\
\hline & Prevention of natural hazards & yes & yes & yes & Pure public good \\
\hline \multirow{4}{*}{ 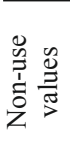 } & Option value & yes & yes & yes & Pure public good \\
\hline & Quasi-option value & yes & yes & yes & Pure public good \\
\hline & Existence value & yes & yes & yes & Pure public good \\
\hline & Bequest value & yes & yes & yes & Pure public good \\
\hline
\end{tabular}

PG: Public good; Cap. limit: Capacity limit

Source: MAYER 2013, 70; based on DIXON/SHERMAN 1990, 26 and FLÜCKIGER 2000, 38; slightly changed

Fig. 1: Costs and benefits of protected areas on the national and regional economic level

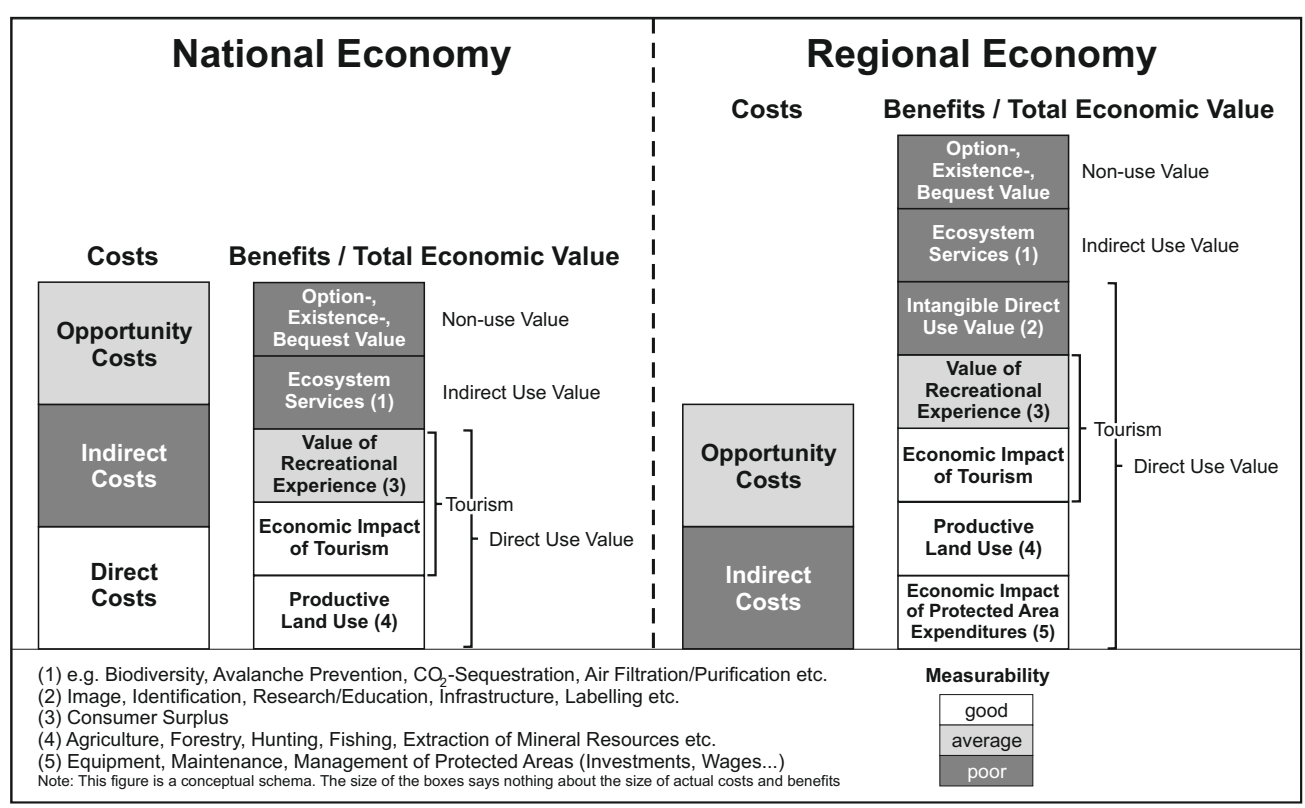

Source: MaYer 2013, 122; based on Dixon/Sherman 1991; Wells 1992; MunASINGHe 1992; KüPfER 2000, JoB et al. 2003; slightly changed 
The TEV can be expressed by a simple formula (Munasinghe 1992, 229; Pearce/Moran 1994, 19):

$$
\begin{aligned}
& \mathrm{TEV}=\mathrm{UV}+\mathrm{NUV}= \\
& (\mathrm{DUV}+\mathrm{IUV}+O V+Q O V)+(\mathrm{XV}+\mathrm{BV}+O V)
\end{aligned}
$$

UV: Use value

NUV: Non-use value

DUV: Direct use value

IUV: Indirect use value

OV: Option value

QOV: Quasi-option value

$\mathrm{XV}$ : Existence value

BV: Bequest value

Most importantly, use (UV) and non-use values (NUV) are distinguished, whereas UV can be further separated into direct (DUV) and indirect (IUC) use values. The NUV consist of existence and bequest values which are not always straightforward to assess empirically. Option and quasi-option values are put in italics here to underline their contested status as TEV components due to the ongoing debate (HANLEY/BARBIER 2009, $40 \mathrm{f}$.). However, OV can refer either to UV or to NUV.

The DUV consist of the economic impact of PA expenditures, the productive use of PA, the economic impact of PA tourism, the value of the recreational experience and intangible DUV (Fig. 1).

- The economic impact of PA expenditures refers to the impact of wages of PA staff and investments in the surrounding region in terms of income and employment (RUCK 1990; KÜPFER 2000; CONNER 2007).

- Productive use of PA stems from resources which are harvested, exploited and sold on markets as private goods (e.g. the selling of timber felled in the buffer zone of a PA) (BLAIKIE/JEANRENAUD 1997).

- The economic impact of tourism refers to the actual expenditures of PA visitors in the surroundings for accommodation, food and hospitality. In economic valuation terminology these expenditures represent the visitors' revealed willingness to pay (WTP) and thus, a quasi-market price for recreation in PA (MoISEY 2002, 235 f.). An important characteristic of the economic impact of tourism are leakages in the form of intermediate input, profits and taxes which reduce the tourism addedvalue. This means that economic impact con- sists of tourism expenditures minus leakages (HJERPE/KIM 2007). In a regional economic perspective only the money actually remaining in the survey region is relevant.

- The value of the recreational experience in PA refers to the consumer surplus of visitors measured in their maximum willingness to pay for PA visitation minus their actual expenditure, that is the difference between the WTP and the actual expenditure which is the consumer surplus of PA visitation. This is because the maximum WTP of PA visitors, which differs individually, is not revealed completely by visitors' expenditure. Consequently, the economic impact only constitutes a subset of the tourism benefits of PA. It does not equal the economic value of recreational use (DIXON/ SHERMAN 1990; CARLSEN 1997; MoISEY 2002).

- Intangible direct use values could be described as effects of PA on image, marketing, research, education or identification as well as infrastructural improvements caused by PA (JOB et al. 2003).

Following Pascual et al. $(2010,196)$ the indirect use values of PA are associated with ecosystem services like e. g. biodiversity protection, air and water purification or $\mathrm{CO}_{2}$ sequestration. The economic valuation of ecosystem services related to PA or not has been the focus of research in recent years, see for instance the TEEB project on the international (PASCUAL et al. 2010) or German level (VON HAAREN 2014).

The non-use values of PA are defined by the WCPA $(1998,12)$ as "values which humans hold for a protected area which are in no way linked to the use of the protected area". They reflect the satisfaction that individuals derive from the knowledge that parks are maintained (existence value) and that other people have or will have access to them (altruistic or bequest value) (PASCUAL et al. 2010, 196).

In this way the total economic valuation differs from a pure financial analysis of payment flows as it tries to include the value components which are not directly quantifiable in monetary terms (Pearce/Turner 1990, $129 \mathrm{ff}$.). Furthermore the TEV concept is practically useful because it demands the consideration of all value components of PA in contrast to a limitation to marketable goods (EDWARDS/ABIVARDI 1998, 241). There- 
fore the TEV is suitable for the economic valuation of PA benefits which - due to the diversity of their functions - cannot be regarded as just one good creating one benefit, or as the WCPA $(1998,11)$ puts it: "The concept of total economic value is now a well-established and useful framework for identifying the various values associated with protected areas."

However, it is important to note that there is no consistent usage of the TEV terminology in the literature and that there is no consensus about the ideal form of the TEV formula. Some authors see the intrinsic values as part of the existence values; others assign intrinsic values to the option values (PEARCE/Turner 1990, 132; ROMMEL 1998, 61). Further authors underline that the TEV does not include intrinsic values at all (WCPA 1998, 11; Pearce/Moran 1994, 22). This situation is consequently reflected in diverging visualizations of the TEV concept. Our version merges ideas from BARBIER $(1991,85)$, MunAsinghe (1992, 229), Job et al. (2009a, 18) as well as PASCUAL et al. $(2010,195)$ and takes the contested role of option values into account (Fig. 2).
Importantly, in the economic valuation of PA the costs or benefits of one stakeholder can at the same time constitute the costs or benefits of another stakeholder. RUCK $(1990,116 \mathrm{f}$.) and the WCPA $(1998,16,19)$ mention the direct costs of PA covered by the state or the taxpayers, which on the regional scale constitute a benefit because of income transferred to the PA region in form of investments or staff wages. Similarly, the forestry use of a PA can be measured either on the cost (as opportunity costs because of the banning of forestry in core zones) or the benefit side (as part of productive land use in buffer zones), depending on the perspective (MAYER 2014).

The conceptual scheme (Fig. 2) takes into account that costs and benefits of PA occur or have to be analyzed on different spatial levels. On the regional scale, for example, normally no direct costs accrue because of PA funding by the national or federal state governments. On the national scale the economic impact of PA expenditures should not be considered, because this benefit turns out to be a distributive effect. The intangible direct use values are also only relevant on the regional level due to their limited range

Fig. 2: Total economic value (TEV) of protected areas

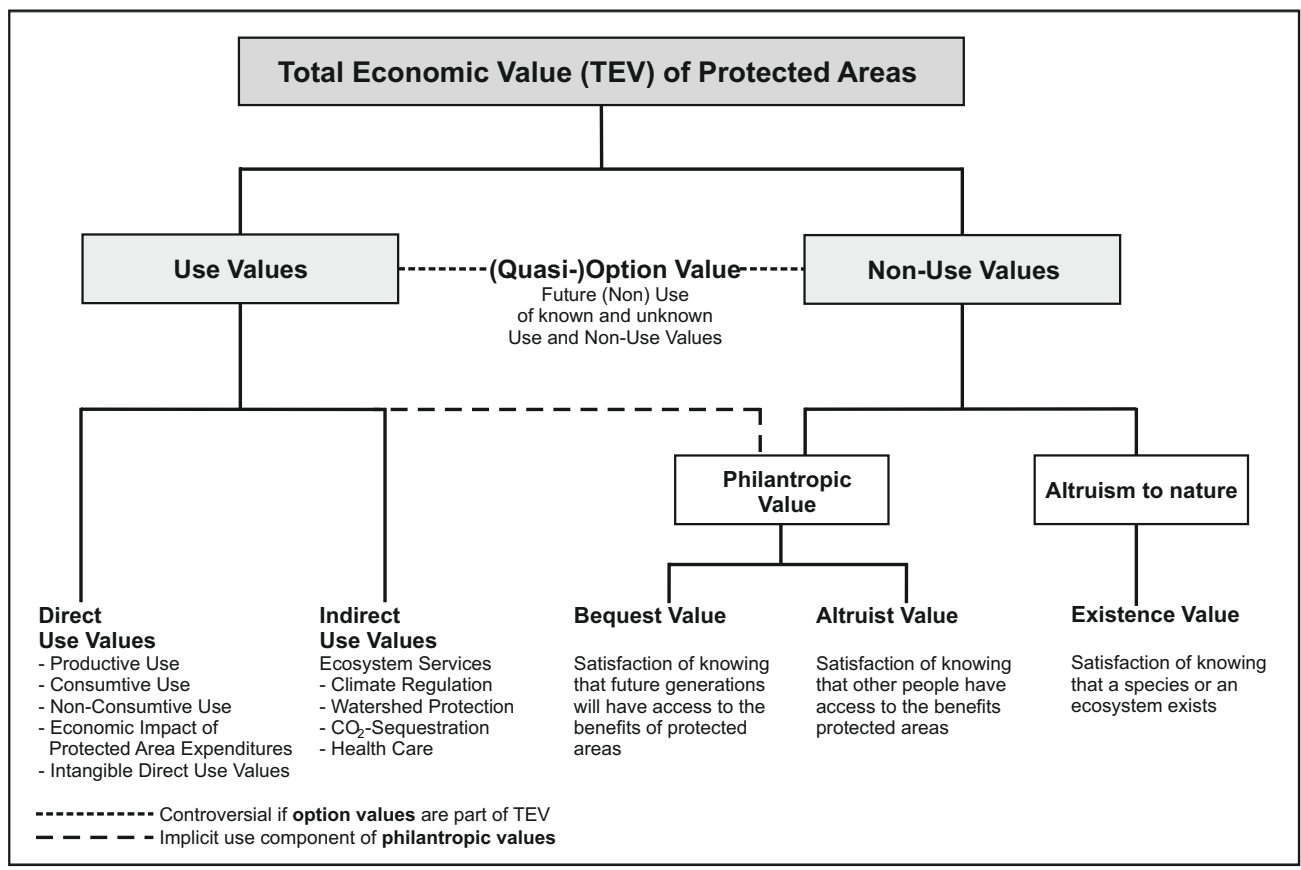

Source: MAYER 2013, 108; based on BARBIER 1991, 85; MunASINGHe 1992, 229; JoB et al. 2009a, 18; PASCUAL et al. 2010,195 
(MAYER 2013, 120). Concerning tourism there is an ongoing debate whether the economic impact of tourism should be used on a national scale, because the impacts of domestic tourism represent distributive effects (KüPFER 2000, 68f.) - these visitors would have spent their vacation in their home country anyway or would have visited another PA in their home country instead (e. g. Baltic Sea area in Germany vs. German Alps). With the expenditure of incoming tourists providing additional input for the national economy only, it is this impact which should be included in a costbenefit framework (SCHÖNBÄCK et al. 1997, 191; BAASKE et al. 1998, 159f.). However, one might also argue that a domestic trip to a PA avoids an overseas trip leading to leakage from the national economy. This is of special importance for countries like Germany with a traditional negative travel balance (e. g. - EUR 35.6 bn in 2012; Destatis 2013, 424).

If one applies a cost-benefit framework as a standard tool in environmental economics to the economic valuation of PA, the following decision rules can be used to aswer the question of whether a PA or its land use / development alternative is economically beneficial (PEARCE/MoRAN 1994, 28):

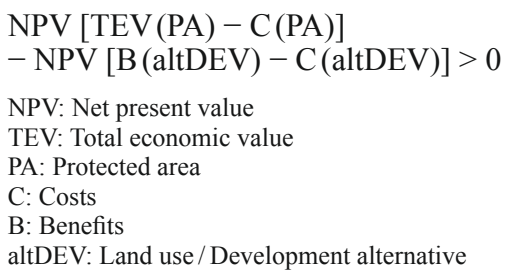

The net present value (NPV) of a PA should surpass the NPV of the next best land use alternative, if nature protection were given preference over this development alternative (PEARCE/MoRAN 1994, 24). The opportunity costs of PA are hidden in the second part of this equation while $\mathrm{C}(\mathrm{PA})$ consists of the direct and indirect costs of PA. Hanley/Barbier (2009, 268f.) further simplify this decision rule: a PA is economically profitable if

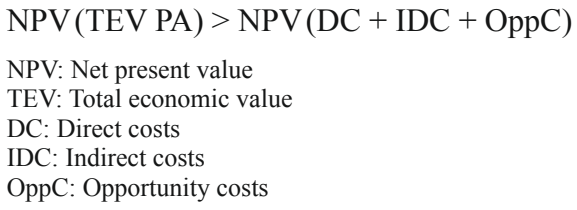

HAMPICKE $(1996,23)$ considers this rule as trivial but useful: If the benefits surpass the costs, then a PA should be realized. Nevertheless, he states that this benefit-cost relationship must not be the only criterion when it comes to the decision about the use of nature. If sustainability is taken into account the existence of PA can also be justified in case of unprofitability, because PA contribute to the preservation of nature for future generations which constitutes the major ecological constraint (HAMPICKE 1996, 24 f.).

From an economic geography perspective, the spatial distribution of PA costs and benefits is decisive. For developing countries WeLLS (1992) identified the following tendencies of spatially unevenly distributed costs and benefits of PA:

- On a local level, the productive use and tourism income are the most prominent benefits of PA, but on the global level both are of minimal importance. This is not surprising as both benefit categories directly affect the basic needs and the income of the local population in and around PA (WELLS 1992, $237 \mathrm{f}$.).

- The non-use values and indirect use values are at best of moderate importance for the local level. However, these benefit categories can be extremely important on a global level although they are difficult to measure or to value (WeLls 1992, 238).

- The direct costs of PA are covered as state expenditure on the federal/national levels, but the indirect costs by the surrounding communities and neighbors of the PA. This means that the opportunity costs of PA occur on the local level as well as on the regional and national level (WeLls 1992, 241 f.).

In general this means that the economic benefits of PA though varying spatially are limited on the local level, increase on the regional/national level and become important on the global level. The costs of PA follow a contrary trend: important locally, moderate regionally and nationally and marginal from the global perspective (WELLS 1992, 243). This uneven distribution of costs and benefits of PA is one of the major reasons for a lack of acceptance of PA among local populations who often see their possibilities to earn a living from local resources limited by PA (Wells 1992, 242; Munasinghe 1992, 232).

These considerations notwithstanding it is not quite clear whether they also hold true for indus- 
trialized, highly developed and densely populated countries in Central Europe. Based on empirical results in the Bavarian Forest National Park (see MAYER 2013, $446 \mathrm{ff}$.), we abstracted Fig. 3 to show the complexities of economic in- terdependencies and interactions in the form of payments, opportunity costs and intangible values between PA, the surrounding region, the national economy, state budgets, PA visitors and businesses.

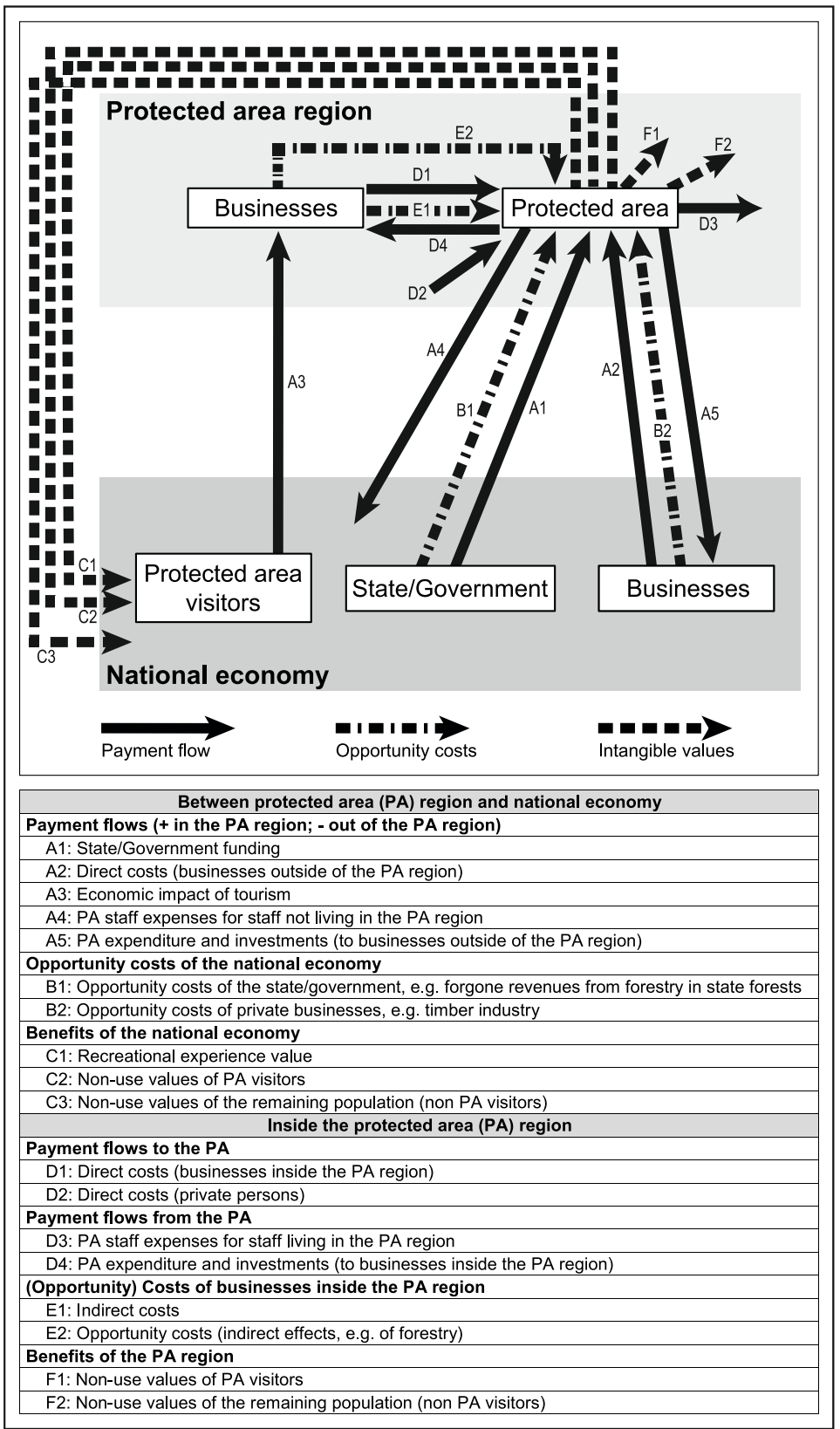

Fig. 3: Economic interactions (payments, opportunity costs, intangible values) between protected areas, the surrounding region, the national economy, state budgets, protected area visitors and businesses Source: own draft, based on MAYER 2013, $452 \mathrm{ff}$. 
In industrialized countries and especially Central Europe, the majority of direct costs of PA are born by the state budgets as well as most opportunity costs because large parts of PA have been designated on state-owned areas like state forests. Businesses in and outside the PA region the identification of which is often open to debate because it clearly influences the outcome of economic valuation of PA - also cover opportunity costs of PA (for example if the timber industry suffers from reduced logging in PAs) but at the same time profit from PA investments. The PA region profits from the influx of money from outside due to the economic impact of PA tourism, whereas the society as a whole gains the intangible values of the recreational experience value of PA visitors. Other important profits of the PA region are the expenditure of PA for staff living in the PA region and investments for local businesses. Thus, as long as the federal or national government provides sufficient funding for PA which also attract a significant number of visitors, the PA region in industrialized countries should profit economically from PA designation, more so as the bulk of opportunity costs is covered by the government budget (see JOB/MAYER 2012).

\section{Economic valuation of European pro- tected areas: a literature review}

This section provides an overview of the economic valuation of PA in the German-speaking countries. The following questions are analyzed:
- Which PA were valuated in which countries?

- What were the aims of the valuation studies?

- What value categories were analyzed?

- What kind of valuation methods was used?

- What PA categories were analyzed?

- What were the main results?

One major problem in preparing this literature review is the prevalence of unpublished studies, project reports, consulting and qualification work. Due to the complexity of comprehensive valuation studies the traditional scientific article is more often than not an inadequate publication form. Furthermore, it is not straightforward to get valuation results published in reviewed journals if there is only little methodological innovation as existing methods are applied to a different survey area. These things considered the following review is likely to be incomplete. Further studies deal with the same issues of economic valuation of nature, nature-based tourism or environmental protection measures but not explicitly in a PA context. Some of these studies are integrated in the following.

The valuation methods can be differentiated basically into three main categories (Tab. 2): direct market valuation approaches, revealedpreference approaches and stated-preference approaches. Other important criteria are the data sources (original research vs. secondary data) and the type of survey (on field in PA regions, in source areas of PA visitors, online).

Tab. 2: Categories of environmental economic valuation approaches and methods

\begin{tabular}{lll}
\hline & $\begin{array}{l}\text { Market price-based } \\
\text { approaches }\end{array}$ & $\begin{array}{l}\text { Economic impact analysis (Wertschöpfungsmethode) } \\
\text { Budget impact analysis (Inzidenz-Analyse) } \\
\text { (Time series analysis) }\end{array}$ \\
\cline { 2 - 3 } $\begin{array}{l}\text { (a) Direct market } \\
\text { valuation approaches }\end{array}$ & $\begin{array}{l}\text { Opportunity cost method } \\
\text { Avoided-cost method } \\
\text { Replacement-cost method } \\
\text { Cost-based approaches }\end{array}$ & Mitigation/Restoration-cost method \\
\cline { 2 - 3 } & $\begin{array}{l}\text { Production function-based } \\
\text { approaches }\end{array}$ & Factor income \\
\hline $\begin{array}{l}\text { (b) Revealed-pre- } \\
\text { ference approaches }\end{array}$ & $\begin{array}{l}\text { Travel cost method (TCM) } \\
\text { Hedonic pricing method }\end{array}$ \\
\hline (c) Stated-preference & Contingent valuation method (CVM) \\
approaches & Choice modelling & \\
\hline
\end{tabular}

Source: MAYER 2013, 126; based on PASCUAL et al. 2010, $204 \mathrm{f}$.; FARBER et al. 2002, $388 \mathrm{f}$. 
One major factor influencing the results of the economic valuation of PA at least on the regional scale is the differing size and delimitation of survey areas. This influence is two-fold: First, if the number of PA visitors is not determined by visitor counting but by using tourism statistics of adjacent municipalities the choice of the survey area directly changes the visitor number of the PA and thus also the economic impact of tourism. Second, in the case of economic impact studies the magnitude of multipliers depends heavily on the size of the survey region (ARCHER/FLETCHER 1996). Thus, a larger survey area leads to higher economic impact of PA. Therefore BLuM (1999, $96 \mathrm{f}$.) even argues that there could never be an unambiguous regional economic valuation because there are no objective criteria to delimitate survey areas. Nevertheless, for practical regional economic valuation tasks of PA the delimitation of survey areas or $P A$ destinations is unavoidable. HANNEMANN/JoB (2003) point out, that the different PA categories also lead to differing delimitations of PA destinations: While visitors of nature parks and biosphere reserves find all relevant tourism infrastructure inside the PA, national parks per definition contain only very few of these value-chain elements. Thus, a national park destination encompasses the buffer zone of the park and the adjacent communities outside the park where the majority of tourism infrastructure is located.

An issue related to the survey area delimitation is the question whether the local population should be included in valuation studies as PA visitors, for example. On the one hand it could be argued that locals do not bring any extra value into the survey area but on the other they avoid spending their money outside the survey area and thus reduce leakage (MAYER 2013, 132). In the case of national parks which are mostly unsettled, this question relates to the neighboring municipalities. For biosphere reserves and (regional) nature parks which contain settlements this issue is even more relevant (JOB et al. 2013a). Consequently at least the share of local visitors and their economic impact should be determined and communicated.

One common characteristic of European PA is the free-access policy in contrast to national parks in the USA, Canada or African countries, which leads to a lack of visitor numbers. Furthermore, the PA category has important consequences for the methodology as in most cases only national parks have a limited number of entry points which enables a concise visitor counting decisive for tourism impact analysis. In the case of biosphere reserves, (regional) nature parks and other less strict PA categories the estimation of the visitor number is hampered by the fact that settlements are situated inside the PA and thus local people have to be taken into account (JOB et al. 2013a, $47 \mathrm{ff}$.). Due to the cultural landscape character of these categories, which do not often show significant differences compared to the landscape outside of these PA, a lot of visitors are not even aware that they are inside a PA or they do not know much about these PA. The latter phenomena challenge the assessment of the role PA play for destination choice. Furthermore the traditional land uses in those PA categories are in most cases only slightly impaired by environmental regulations which complicates the estimation of opportunity costs. For example, the causality of an economic underperformance is difficult to prove: are the businesses not successful due to the PA restrictions or due to their peripheral location or their limited entrepreneurial capabilities/innovativeness?

The categorization of the existing valuation studies of PA in German-speaking countries into eight groups is shown in Tab. 3. Each group is structured chronologically: (a) economic impact of tourism, (b) time series analysis of tourism development, (c) budget analysis, (d) applications of the travel-cost method, (e) contingent valuation studies, (f) opportunity cost analyses, (g) cost-benefit analyses, and (h) other studies (for an overview of studies referring to the latter and focusing on destination choice and PA see PRÖBSTL-HAIDER/HAIDER 2014).

\section{Economic impact analysis of tourism}

Without any doubt the valuation of the economic impact of tourism induced by PA is by far the largest group of valuation studies of PA in German-speaking countries. This kind of study set the starting point for the economic valuation of PA in this part of Europe in the early 1980s when KLEINHENZ (1982) analyzed the economic impact of tourism in the first German national park founded in 1970, the Nationalpark Bayerischer Wald. For the first time KLEINHENZ (1982) could prove that PA tourism is able to contribute significantly to regional development in peripheral rural areas. However, it was only nearly two decades later when KÜPFER's (2000) study about the Swiss National Park established the basic methodology for economic impact analysis of PA tourism in German-speaking Europe, applying not only the economic impact analysis 
methodology of RÜTTER et al. $(1995,1996)$ to PA for the first time, but also establishing a method of assessing the role of the PA category for the travel decision of PA visitors which is now wellestablished (ARNBERGER et al. 2012) and similar to an approach used by WALL REINIUS / FREDMAN (2007) which is based on LEIPER's (1990) idea of markers. KÜPFER's (2000) approach was applied by Јов et al. (2003) for eleven of fifteen German national parks (a twelfth park was analyzed by REIN/SCHNEIDER 2009), two nature parks, six biosphere reserves and several other PA around the globe using small but relevant methodological adaptations - in order to achieve a stricter identification of visitors with a high PA affinity - which impede direct comparisons of results.

Extrapolated for all German national parks there are about $50.9 \mathrm{~m}$ visitors per year generating a gross turnover of 2.1 bn $€$ and 69000 income equivalents. The two Wadden Sea National Parks dominate these results with a share of about $80 \%$. For all national parks, the average share of visitors with a high national park affinity is $20.6 \%$ leading to $10.5 \mathrm{~m}$ visitors and gross turnover of $431 \mathrm{~m} €$ per year generating 14000 income equivalents. The total income from tourism for the twelve national parks analyzed totals $183.1 \mathrm{~m} €$ for the visitors with a high park affinity and 1.196 bn $€$ respectively for all national park visitors (for methodological reasons without Berchtesgaden). The share of visitors mainly motivated by the national park status varies between $10.1 \%$ in Berchtesgaden and $45.8 \%$ in Bayerischer Wald (JoB et al. 2003, 132; 2005, 70; 2009a, 152 ff.; 2010, 28; 2014a, 67; 2014b, 65; Woltering 2012; ReIN/SCHNEIDER 2009; MAYER et al. 2010, 80). The extrapolated results for the German biosphere reserves total $4.2 \mathrm{~m}$ visitors motivated by the BR status per year generating gross turnover of about $181.5 \mathrm{~m} €$ and 5261 income equivalents (JоB et al. 2013a, 97).

It is obvious from the results presented in Tab. 3, that the national park label in general has a stronger attractiveness compared to biosphere reserves (in Germany, the share of high PA affinity visitors varies between $3.5 \%$ in the BR Pfälzerwald and $21.5 \%$ in BR Schaalsee; in Switzerland between $12 \%$ in BR Val Müstair and $16 \%$ in Entlebuch) or nature parks (17\% visitors with a high PA affinity in Rieserferner-Ahrn, Italy, $15.3 \%$ in the Altmühltal and $4.1 \%$ in Hoher Fläming, both Germany), but its variability is also higher. That means it is crucial to analyze the role of PA for destination choice for which the share of high PA affinity visitors serves as an important indicator. Thus it makes sense to compare only the economic impact of this visitor core group which is likely to be motivated by the PA in the first place.

In general, the economic impact analyses of PA tourism prove that PA play a very important role in nature-based tourism in the mostly peripheral rural PA regions in the German-speaking countries, where they are often part of implicit or explicit regional development strategies which aim at reducing disparities by stimulating tourism. Additionally, the considerable number of case studies in German PA using the same methodology serves as the base data necessary for a national socioeconomic PA monitoring system (WOLTERING 2012), which will be established in 2016 finally.

\section{Time series analysis of tourism development and protected areas}

The different time series studies analyzing the impact of PA on tourism development based on official statistics of overnight stays provide no real economic valuation studies but also represent market-based impact analysis (BACHLEITNER/Weichbold 2004; SCHMid 2006; GeTZNER 2008). They show mixed results in that a PA designation (only national parks have been analyzed so far) does not necessarily lead to a boost in tourism development. This fact is clearly related to the respective phase of the PA destinations in the TALC (BUTLER 1980). It is obvious that a destination in the decline phase would not show the same positive results of a PA designation as can be observed in destinations in the development or growth stage. Furthermore, PA cannot be regarded as sure-fire successes for tourism development in any case. They need commitment of all local and regional stakeholders, a professional destination management, a consistent marketing strategy and an attractive accommodation as well as gastronomy offer and, last but not least, appealing nature-based products.

\section{Studies analyzing protected area's budgets}

As a common characteristic of these studies they analyze the economic impact of PA budgets on the regional economy surrounding PA by either modeling the effects with input-output approaches or the direct analysis of payment and good flows to and from PA. As expected the results depend strongly on the size of PA budgets. For example, Scheurer/SteIger (1993, 144) 
show that the management of the Swiss National Park only leads to limited economic impact of $1.83 \mathrm{~m}$ CHF per year. $64 \%$ of the park's expenditure remains in the PA region amounting to $0.34 \%$ of the regional income. Consequently, they state that national parks as such are not suitable to reduce regional disparities. SCHERER/ SCHULTZ $(1997,31 \mathrm{f}$.) report an annual economic impact of $1.28 \mathrm{~m} €$ from the budget of the German biosphere reserve Oberlausitzer Heide- und Teichlandschaft. The authors speak of an important, but again limited effect. KLETZAN/KRATENA (1999) sum up the regional economic output of all Austrian national park budgets. $23.98 \mathrm{~m} €$ per year leads to the direct employment of 128 persons and 322 persons in total. A study of the Akademie für Umweltforschung und -bildung in Europa (AUBE) e.V. (2003) reveals that nine out of 13 German national parks employ 655 persons in their administrations. Thus, the authors conclude that the economic impact of park budgets should not be underestimated, especially as PA provide job opportunities for highly qualified persons in peripheral areas where those jobs are rare (JOB/MAYER 2012, 137).

JoB et al. (2014a, $105 \mathrm{ff}$.) determined that the economic impact of the visitor center Multimar Wattforum in the German national park Schleswig-Holsteinisches Wattenmeer (181 571 visitors per year on average) totals $1.996 \mathrm{~m} €$ per year. Compared with the yearly subsidies of $0.686 \mathrm{~m} €$ this points to a considerable multiplier effect of 2.91. A total of 42 employees is complemented by an income equivalent of 105 persons generated by the expenditures of visitors as well as indirect and induced effects.

\section{Applications of the travel-cost method}

In German-speaking countries FeIGE et al. (1995), SCHÖNBÄCK et al. (1997) and MAYER $(2013,2014)$ undertook applications of the travel-cost method in a PA context. FeIGE et al. (1995, $100 \mathrm{ff}$.) determined for the German national park SchleswigHolsteinisches Wattenmeer only the gross willingness to pay (WTP) for the recreational experience by multiplying the assumed travel costs with the visitor number: 266000 visitors had a WTP of $3.87 \mathrm{~m} €(14.55 €$ per visitor). SCHÖNBÄCK et al. (1997, 192 f.) calculated a consumer surplus for recreation in the intended Austrian Donauauen National Park of $2.29 \mathrm{~m} €(2.54 €$ per visitor). This comparatively low per capita value stems from the extremely high share of day-trippers from the agglomeration of Vienna.
Tab. 3: Overview of valuation studies of protected

PA category and name, country

Economic impact of tourism

NP Bayerischer Wald, FRG

NP Schweizer Nationalpark, $\mathrm{CH}$

NP Berchtesgaden, FRG

NP Hohe Tauern, AT

NuP Rieserferner-Ahrn, IT

NP Schleswig-Holsteinisches Wattenmeer, FRG

NP Müritz

NuP Altmühltal

NuP Hoher Fläming, all FRG

NuP Landseer Berge

NuP Geschriebenstein-Irrotkö

$\mathrm{NuP}$ in der Weinidylle

NuP Raab-Örség-Goričko, all AT

NP Bayerischer Wald

NP Eifel

NP Hainich

NP Kellerwald-Edersee

NP Niedersächsisches Wattenmeer

NP Sächsische Schweiz

NP Schleswig-Holsteinisches Wattenmeer

NP Hamburgisches Wattenmeer (included in NI \& SH Wm)

NP Harz, all FRG

NP Unteres Odertal, FRG

NuP Diemtigtal, CH (ex-ante)

BR Biosphere Entlebuch, $\mathrm{CH}$

NP Schweizer Nationalpark

BR Biosfera Val Müstair, all CH

BR Rhön

BR Vessertal-Thüringer Wald

NuP/BR Pfälzerwald

BR Schaalsee

BR Spreewald

BR Südost-Rügen, all FRG

Time series analysis

NP Hohe Tauern, AT

all NP in Germany, FRG

NP Hohe Tauern, AT 
areas in German-speaking countries/regions

Authors

Methods / Aim / Value categories

Main Results

\begin{tabular}{lll} 
KLEINHENZ 1982 & Visitor and tourism business survey & $1.7 \mathrm{~m}$ visitors; TEI of HPAA $5.6 \mathrm{~m} € ; 30.5 \%$ HPAA \\
\hline KÜPFER 2000 & Visitor and tourism business survey & $0.536 \mathrm{~m}$ visitors; TEI $17.4 \mathrm{~m}$ CHF; $41.9 \%$ HPAA \\
\hline JoB et al. 2003 & Visitor survey & $1.13 \mathrm{~m}$ visitors; TEI of HPAA tourism $4.6 \mathrm{~m} € ; 10.1 \%$ HPAA \\
\hline LEHAR et al. 2004 & Visitor survey & $1.75 \mathrm{~m}$ visitors; $16 \%$ HPAA; TEI of HPAA $2.65 \mathrm{~m} €$ \\
& & $1.1 \mathrm{~m}$ visitors; $17 \%$ HPAA; TEI of HPAA $2.71 \mathrm{~m} €$ \\
\hline KoRFF 2004a, b; & Visitor survey & TEI optimistic: $131 \mathrm{~m} €$, pessimistic $6.4 \mathrm{~m} € ; 25 \%$ HPAA over- \\
TRIMBORN 2006 & & night guests; $16 \%$ HPAA day-trippers \\
JoB et al. 2005; & Visitor survey & $0.39 \mathrm{~m}$ visitors; $43.7 \%$ HPAA; TEI $6.9 \mathrm{~m} €$ TEI HPAA $2.8 \mathrm{~m} €$ \\
JoB/METZLER 2005 & & $0.91 \mathrm{~m}$ visitors; $15.3 \%$ HPAA; TEI $10.3 \mathrm{~m} €$ \\
& & $0.3 \mathrm{~m}$ visitors; $4.1 \%$ HPAA; TEI $3.0 \mathrm{~m} €$
\end{tabular}

HeINTEL/WEIXL- Visitor survey

BAUMER 2009;

all NuPs: $19.3 \%$ HPAA

WEIXLBAUMER et al.

2007

$0.052 \mathrm{~m}$ visitors, $20.7 \%$ HPAA, TEI $1.2 \mathrm{~m} €$; TEI HPAA $0.252 \mathrm{~m} €$

JoB et al. 2009a, 2010, 2014a, b;

Visitor survey and (tourism) business survey visitor days $(\mathrm{m}) \quad$ HPAA $(\%) \quad$ TEI $(\mathrm{m} €) \quad$ TEI HPAA $(\mathrm{m} €)$

MAYER et al. 2010; (Bayerischer Wald only)

$0.45 \quad 27.3$

$45.8 \quad 13.5$

13.5
4.3

27.3

0.29

40.7

0.20

25.8

2.5

1.4

WOLTERING 2012

\subsection{5}

1.70

10.9

28.8

1.9
525.0

29.3

18.64

1.75

24.4

39.6

89.2

REIN/SCHNEIDER Visitor survey

0.21

31.6

0.9

9.1

2009

MAYER et al. 2009 Visitor survey

$\sim 82000$ visitor days (2005/06), TEI $1.62 \mathrm{~m} \mathrm{CHF}$

KNAUS 2012

Visitor survey, visitation

$0.6 \mathrm{~m}$ visitors; TEI $5.2 \mathrm{~m} \mathrm{CHF}$; $16 \%$ HPAA

based on secondary data

BACKHAUS et. 2013 Visitor survey, visitation based on secondary data

$0.544 \mathrm{~m}$ visitors; $19.7 \mathrm{~m} \mathrm{CHF} ; 35 \%$ HPAA

$0.08 \mathrm{~m}$ visitors; TEI $3.8 \mathrm{~m}$ CHF; $12 \%$ HPAA

JoB et al. 2013a

Visitor survey and (tourism)

$\begin{array}{cccc}\text { visitor days }(\mathrm{m}) & \text { HPAA }(\%) & \text { TEI }(\mathrm{m} €) & \text { TEI HPAA }(\mathrm{m} €) \\ 6.37 & 13.7 & 94.6 & 12.1 \\ 0.49 & 11.1 & 6.4 & 0.7 \\ 5.72 & 3.5 & 116.2 & 3.6 \\ 0.49 & 21.5 & 5.7 & 1.5 \\ 1.94 & 8.7 & 47.4 & 4.0 \\ 5.29 & 4.9 & 203.9 & 10.9\end{array}$

BACHLEITNER/

WeICHBOLD 2004

SCHMID 2006

GETZNER 2008 business survey (Rhön only)

Time series analysis of

overnight stays

Time series analysis of tourism in national park counties compared with structurally similar counties

Time series analysis of overnight stays

\section{No clear NP influence}

Mixed results; hypothesis that NP designations generally boost tourism development cannot be confirmed

Positive effect of NP designation on tourism development (after five to seven years); but no short-term effects on overnight stays 
Other TCM studies do not refer to PA but to landscapes like the Southern Harz, Pfälzerwald or Lüneburger Heide which represent naturebased tourism destinations in Germany. BERGEN/ LÖWENSTEIN (1995 [1992], 35) and LÖWENSTEIN $(1994,112)$ estimated that the inflation adjusted (1993 to 2007) consumer surplus for overnight recreational stays in the Southern Harz varies between $27.87 €$ and $35.65 €$ or $31.12 €$ and $31.76 €$ respectively. As LUTTMANN/SCHRÖDER $(1995,39)$ found out, the consumer surplus of overnight visitors in the Lüneburger Heide is of about the same magnitude $(26.84 €$ per person and visit). ELSASSER (1996, $181 \mathrm{ff}$.) measured the consumer surpluses of forest visitors in the Pfälzerwald (biosphere reserve since 1993 and nature park since 1959) and differentiated between vacationists (15.68 € per visit) and daytrippers $(0.76 €$ per visit). These values prove the reliability of MAYER's $(2013,2014)$ results from the Nationalpark Bayerischer Wald where the consumer surplus per visitor day varies between $19.57 €$ and $28.97 €$ depending on the model specification and cut-off points. As MAYER (2014) shows, the recreational values of PA estimated with travel cost models can surpass the tangible economic impact of PA tourism considerably, at least from a national economic perspective. Thus, this value component of PA should no longer be neglected in future as this leads to a significant underestimation of the TEV of PA.

\section{Contingent valuation studies}

Similar to the limited application of TCM only few contingent valuation studies in Germanspeaking PA have been realized. For the projected Austrian Nationalpark Donauauen Kosz (1996) and SCHÖNBÄCK et al. (1997) revealed that $75.2 \%$ of the respondents had a positive WTP for "solution II" of on average $5.68 €$ per park visit (aggregated $3.84 \mathrm{~m} €$ ). Additionally they found out that an average WTP of $4.65 €$ per Austrian citizen and year would be sufficient for the national park project to equal the most efficient hydro power plant project. The ex-ante evaluation of HACKL (1997) and BAASKE et al. $(1998,165 \mathrm{f}$.) of the national park project Oberösterreichische Kalkalpen, Austria, is so far the only study of PA in German-speaking countries explicitly incorporating non-use values. With the help of a CVM they derived aggregated non-use values for the PA project of $1.53 \mathrm{~m} €$ (or $2.5 €$ per capita). RoMmeL (1998) analyzed the WTP of the local population and of visitors
Budget analysis (Inzidenzanalyse)*

NP Schweizer Nationalpark, CH

BR Oberlausitzer Heide- und Teichlandschaft, FRG

NP Donau-Auen

NP Neusiedlersee-Seewinkel

NP OÖ Kalkalpen

NP Hohe Tauern, all AT

NP Gesäuse, AT (ex-ante)

9 out of 13 German national parks, FRG

NP Bayerischer Wald, FRG

NP Schleswig-Holsteinisches Wattenmeer, FRG

Applications of the travel-cost method

NP Schleswig-Holsteinisches Wattenmeer, FRG

NPP Donau-Auen, AT (ex-ante)

NuP/BR Pfälzerwald

NP Bayerischer Wald, FRG

Contingent valuation studies

NPP Donau-Auen, AT (ex-ante)

NPP OÖ Kalkalpen, AT (ex-ante)

BR Schorfheide-Chorin, FRG

NP Bayerischer Wald, FRG

Opportunity cost analyses

NPP Lieberose, FRG (ex-ante)

NP Bayerischer Wald, FRG

BR Vessertal-Thüringer Wald, FRG (ex-ante)

NP Schwarzwald, FRG (ex-ante) 
SCHEURER/STEIGER Budget analysis: Payments flows 1993; ElSASSER et induced by the PA al. 1995

SCHERER/SCHULTZ 1997

KLETZAN/KRATENA 1999
Budget analysis: Payments flows induced by the PA

Input-output analysis of PA investments and compensatory payments for land users
NP leads to financial flows of $1.83 \mathrm{~m} \mathrm{CHF} ; 64 \%$ of NP expenditure remain in the park region ( $0.34 \%$ of regional income); regional economic impact of NP small.

$1.3 \mathrm{~m} €$ (incl. multiplier effects) spent inside the BR. Important but limited contribution to regional economic development.

Total output $23.98 \mathrm{~m} €$

Direct employment 128 persons, in total 322

\section{JUNGMEIER/VELIK Impact analysis of estimated 1999 \\ PA expenditures}

Akademie für Umweltforschung und -bildung in Europa (AUBE) e.V. 2003

MAYER/WOLTERING Budget analysis of visitor center 2008; MAYER 2013

JoB et al. 2014a
Employment and income effects of national park administrations (postal survey)

Haus zur Wildnis
Budget analysis of visitor center
Expenditures of NP $8.16 \mathrm{~m} €$; NP investments $5.3 \mathrm{~m} €$; $\mathrm{NP}$ management costs $2.33 \mathrm{~m} €$; equal to mid-size enterprise 655 employees in NP administrations; ca. $21.7 \mathrm{~m}$ visitors per year in German NPs; economic impact of NP should not be underestimated

Investment $17.66 \mathrm{~m} €$, in the NP region $12.36 \mathrm{~m} €$, regional TEI $6.1 \mathrm{~m} €$; current regional income $0.576 \mathrm{~m} € /$ year; 18 full-time, four part-time jobs in the visitor center; in total 35 jobs 42 employees; 181571 visitors per year (average). Total regional income (2010): $1.996 \mathrm{~m} €$; income equivalents 105 persons. Subsidies (yearly): $0.686 \mathrm{~m} €$; multiplier effect 2.91

Multimar Wattforum

\section{FEIGE et al. 1995 TCM}

SCHÖNBÄCK et al. TCM 1997

ELSASSER 1996 TCM

MAYER 2013, 2014 TCM
Gross willingness to pay (WTP) for recreational experience 266000 visitors - WTP $3.87 \mathrm{~m} €(14.55 €$ per visitor $)$

Consumer surplus for recreation $2.29 \mathrm{~m} €(2.54 €$ per visitor $)$

Consumer surpluses of forest visitors differentiated between vacationists ( $15.68 €$ per visit) and day-trippers ( $0.76 €$ per visit) Consumer surplus per visitor day between $19.57 €$ and $28.97 €$
Kosz 1996; SCHÖN- CVM

BÄCK et al. 1997

HACKL 1997; CVM, non-use values

BAASKE et al. 1998

ROMMEL $1998 \quad$ CVM

MAYER $2013 \quad$ CVM
$75.2 \%$ of respondents positive WTP for "solution II": average WTP $5.68 €$ per park visit (aggregated $3.84 \mathrm{~m} €$ )

Aggregated non-use values of $1.53 \mathrm{~m} €$ (or $2.5 €$ per capita)

WTP locals $25.96 €$ per person and year, WTP visitors $1.54 €$ per person and visit; aggregated WTP $5.1 \mathrm{~m} €$

Aggregated WTP of visitors for potential entrance fees $1.88 \mathrm{~m} € /$ year
JoB et al. 2009b

JOB/MAYER 2012; Opportunity costs

MAYER 2013

JoB et al. 2012

\section{Pricewaterhouse- Opportunity costs}

Coopers/

$\ddot{o}:$ konzept 2013
Economic impact of tourism (Est); Opportunity costs of forestry $0.74-2.89 \mathrm{~m} €$ (annually) TEI of NP tourism higher

Regional opportunity costs of forestry and timber industries: $5.45-6.81 \mathrm{~m} €$

Opportunity costs of forestry (core zone extension of $1000 \mathrm{ha}$ ) $0.24-0,26 \mathrm{~m} €$ (annually), TEI of tourism higher

Opportunity costs of forestry and timber industries: $8.0 \mathrm{~m} €$ ( 110 jobs would be lost) in all processing stages (without promised compensations of raw timber) 
of the German Biosphere Reserve SchorfheideChorin. The locals were willing to pay $25.96 €$ per person and year, the visitors $1.54 €$ per person and visit. The aggregated WTP of locals, the surrounding population and the visitors totaled $5.1 \mathrm{~m} €$. MAYER $(2013,430 \mathrm{f}$.) reports the aggregated WTP of visitors to the German National Park Bayerischer Wald for hypothetical park entrance fees as being $1.88 \mathrm{~m} € /$ year which equals $13.9 \%$ of the ecnomic impact of park tourism (for the year 2007).

\section{Opportunity cost analyses}

Besides the cost-benefit analyses presented below, only few studies dealt with the opportunity costs of PA in the German-speaking countries. JoB et al. (2009b) assessed the opportunity costs of forestry and wood processing industries for the German national park project Lieberose. If forestry use were stopped in an area of between 3000 and 7000 ha annual opportunity costs would vary between $0.74 \mathrm{~m} €$ and $2.89 \mathrm{~m} €$. JoB et al. $(2012,112)$ also estimated the opportunity costs of a potential 1000 ha extension of the core zone of the Biosphere Reserve Vessertal-Thüringer Wald to amount to between $0.239 \mathrm{~m} €$ and 0.261 $\mathrm{m} €$ per year. In both cases, it is likely that these costs would be compensated by an increase in tourism revenues. JOB and MAYER (2012) show for the national park Bayerischer Wald that regional income from PA tourism (EUR 13.5 million) in any case compensates for the regional opportunity costs of forestry and wood processing industries (between $5.45 \mathrm{~m} €$ and $6.81 \mathrm{~m} €$ plus $2.9 \mathrm{~m} €$ income from alternatively existing non-PA tourism). The profits of state-owned forests do not remain in the survey area but flow into the Bavarian state budget, whereas a much higher percentage of income from tourism leads to employment, investments or profits in the surroundings of the PA.

Though the term "opportunity costs" is not directly mentioned, PricewaterhouseCoopers/ $\ddot{o}$ :konzept (2013, $108 \mathrm{ff}$.) analyzed the opportunity costs of forestry and wood processing industries for the in 2014 newly designated German national park Schwarzwald in detail. If the state forest were not compensated for the loss of $39 \%$ to $53 \%$ of the raw timber offers from the park area, saw mills would have to close, which would lead to a decrease in income of about $8.0 \mathrm{~m} €(110$ jobs would be lost) in all processing stages, however, the state forest has stated that they would compensate it.
Cost-benefit analyses

NP Schleswig-Holsteinisches Wattenmeer, FRG

NPP Donau-Auen, AT (ex-ante)

BR Schorfheide-Chorin, FRG

NPP OÖ Kalkalpen, AT (ex-ante)

NPP Teutoburger Wald / Eggegebirge, FRG (ex-ante)

NP Bayerischer Wald, FRG

NP Nordschwarzwald, FRG (ex-ante)

Other studies (secondary data analysis ...)

NPP Thayatal (ex-ante), AT

NP in Austria

Natura 2000 areas

Karwendel

Verwall

Waldviertel, all AT

Extrapolation to all Natura 2000 areas in Austria

NP Hohe Tauern

NP Donau-Auen

NP Neusiedler See;

NP OÖ Kalkalpen

NP Thayatal, all AT

$6 \mathrm{NuP}$ projects in Switzerland

$45 \mathrm{NuP}$ in Austria

NP Hohe Tauern, AT

NP Hohe Tauern, AT

Source area study

NP: National park; BR: Biosphere reserve; NuP: (Regional) Nature * as it seems that there is no common translation for the term "InziSource: adapted from MAYER 2013, $161 \mathrm{ff}$., $535 \mathrm{ff}$. and the mentioned 


\begin{tabular}{|c|c|c|}
\hline FeIGE et al. 1995 & $\begin{array}{l}\text { Economic impact of tourism; } \\
\text { TCM; opportunity costs }\end{array}$ & $\begin{array}{l}2.4 \% \text { HPAA of overnight visitors; TEI HPAA } 5.57 \mathrm{~m} € \text {; } \\
\text { benefits: } 39.2 \mathrm{~m} € \text {; costs } 23.2 \mathrm{~m} € \text {; BCR: } 1.6-1.7\end{array}$ \\
\hline $\begin{array}{l}\text { SCHÖNBÄCK et al. } \\
1997\end{array}$ & $\begin{array}{l}\text { Economic impact of tourism; } \\
\text { TCM; CVM; opportunity costs }\end{array}$ & $\begin{array}{l}\text { BCR: } 0.49-0.99 \text { (complicated because of related river regulation } \\
\text { scenarios for the Danube) (only foreign visitors contribute to TEI) }\end{array}$ \\
\hline ROMMEL 1998 & CVM; opportunity costs & BCR: $1.24-1.25$ \\
\hline BAASKE et al. 1998 & $\begin{array}{l}\text { Opportunity costs; Economic } \\
\text { impact of tourism (Est); CVM }\end{array}$ & $\begin{array}{l}\text { BCR phase } 1: 1.07 \text {, phase } 2: 1.61 \\
\text { (only foreign visitors contribute to TEI) }\end{array}$ \\
\hline $\begin{array}{l}\text { Roland Berger } \\
\text { Strategy Consult- } \\
\text { ants } 2010\end{array}$ & $\begin{array}{l}\text { Economic impact of tourism (Est); } \\
\text { opportunity costs (Est) }\end{array}$ & $\begin{array}{l}\text { Direct costs: } 3-6 \mathrm{~m} € / \text { year for investments and } 40 \text { employees; } \\
\text { opportunity costs forestry: } 2.6 \mathrm{~m} € / \text { year; tourism growth } \\
\text { estimated at } 1-3 \% / \text { year. NP project economically justified. }\end{array}$ \\
\hline MAYER 2013, 2014 & $\begin{array}{l}\text { All benefits and costs besides } \\
\text { non-use values }\end{array}$ & $\begin{array}{l}\text { BCR national level: } 0.427-1.061 \\
\text { BCR regional level: } 1.080-1.591\end{array}$ \\
\hline $\begin{array}{l}\text { Pricewaterhouse- } \\
\text { Coopers/ } \\
\text { ö:konzept } 2013\end{array}$ & $\begin{array}{l}\text { Economic impact of tourism (Est); } \\
\text { opportunity costs (Est) }\end{array}$ & $\begin{array}{l}\text { Opportunity costs (see above) } 8.4-8.5 \mathrm{~m} € / \text { year; visitors estima- } \\
\text { ted } 3.05 \mathrm{~m} \text {; TEI tourism } 10.21 \mathrm{~m} € / \text { year; NP project evaluated } \\
\text { positively }\end{array}$ \\
\hline
\end{tabular}

ITR 1993; Natio- $\quad \begin{aligned} & \text { Secondary data driven estimations } \\ & \text { nalparkplanung }\end{aligned}$
Thayatal-Betriebs-
gesellschaft March-
feldkanal 1995

$\begin{array}{lll}\begin{array}{l}\text { FLEISCHHACKER/ } \\ \text { PAUER 2001 }\end{array} & \text { Secondary data, estimations } & \begin{array}{l}\text { ca. } 400000-450000 \text { visitors only because of NP; } \\ \text { estimated TEI: } 14.2-19.3 \mathrm{~m} €\end{array} \\ \text { GETZNER et al. } & \text { Regional economic modeling } & \text { Karwendel: TEI } 0.65-3.55 \mathrm{~m} € \\ 2002 & \text { based on multipliers, secondary } & \text { Verwall: TEI } 0.02-1.09 \mathrm{~m} € \\ & \text { data, regional workshops and } & \text { Waldviertel: TEI } 0.12-0.44 \mathrm{~m} € \\ & \text { scenario building } & \text { 150 Natura } 2000 \text { regions in AT: } 72.67 \mathrm{~m} € \text { set-up costs (one- } \\ & & \text { time), TEI } 29.1 \mathrm{~m} € \text { (one-time). } \\ & \text { Current expenses: ca. } 10.9 \mathrm{~m} € / \text { year, regional TEI ca. } \\ & 7.27 \mathrm{~m} € / \text { year, at least } 150 \text { permanent full-time jobs }\end{array}$

GETZNER 2003 Postal survey of majors of Austrian $\quad$ NP perceived as positive factors for local and regional economic national park municipalities; development perceived economic impact of PA

TEI of NP infrastructure: $2.4-2.8 \mathrm{~m} €$;

TEI tourism: $1.0-2.3 \mathrm{~m} € /$ year; further TEI: $0.3-0.6 \mathrm{~m} € /$ year; costs of NP infrastructure: $1.4-2.1 \mathrm{~m} €$

national park municipalities;
perceived economic impact of PA

\begin{tabular}{lll}
\hline $\begin{array}{l}\text { SIEGRIST et al. } \\
2006\end{array}$ & Secondary data, estimations & $\begin{array}{l}\text { Realization of three to four NuP projects would generate additi- } \\
\text { onal TEI between } 10 \text { and } 38 \mathrm{~m} \text { CHF/year for the Canton of Ber- } \\
\text { ne, } 6 \text { to } 21 \mathrm{~m} \mathrm{CHF} / \text { year for the NuP regions }\end{array}$ \\
\hline $\begin{array}{l}\text { KETTERER/ } \\
\text { SIEGRIST 2009 }\end{array}$ & Secondary data, estimations & $\begin{array}{l}\text { 9.85 m overnights stays, } 15.9 \mathrm{~m} \text { day trips in Austrian NuP muni- } \\
\text { cipalities; Expenditure of NuP visitors } ~ 144 \mathrm{~m} €\end{array}$ \\
\hline $\begin{array}{l}\text { BODENHÖFER et al. } \\
2009\end{array}$ & $\begin{array}{l}\text { Input-output analysis based on } \\
\text { tourism statistics, PA budget and } \\
\text { secondary data }\end{array}$ & $\begin{array}{l}\text { TEI of tourism: } 16.7 \mathrm{~m} € \text {; TEI of NP investments: } 0.5 \mathrm{~m} € ; \\
\text { TEI of NP management: } 4.5 \mathrm{~m} €\end{array}$ \\
\hline GETZNER 2010 & $\begin{array}{l}\text { Trend analysis of socio-demogra- } \\
\text { phic and socio-economic variables }\end{array}$ & $\begin{array}{l}\text { No measurable effects of NP designation on demographic trends; } \\
\text { since NP designation above average tourism sector growth }\end{array}$ \\
\hline $\begin{array}{l}\text { PRÖBSTL-HAIDER } \\
\text { et al. 2014 }\end{array}$ & $\begin{array}{l}\text { Choice experiment based on online } \\
\text { survey among German tourists } \\
\text { interested in travelling the Alps }\end{array}$ & $\begin{array}{l}\text { Onsite surveys overestimate the importance of PA categories for } \\
\text { travel decisions / motivations. Tourists seek nature experiences } \\
\text { which can be provided by PA regions. }\end{array}$ \\
\hline
\end{tabular}

park; P: Project; Est: Estimation; TEI: Total economic impact; HPAA: High protected area affinity; BCR: Benefit-cost ratio; m: million denzanalyse" used in the German speaking scientific community, we coined the expression "budget analysis"

references 
BLUM (1999, 88, $91 \mathrm{ff}$.) assessed the opportunity costs of different forest conservation programs outside of PA. As the decrease in timber sales revenues is contrasted by cost reductions, the overall economic losses of forestry increased only slightly to reach a quite low level of opportunity costs of $5.39 €$ per ha. KNOKE/MOOG (2005) did not deal with the opportunity costs of PA either, but with the establishment of so-called natural forest areas in beech forests which have nearly the same economic consequences as a PA designation. They show that if $10 \%$ of German beech forests (143000 ha) were not harvested anymore, this would lead to annual opportunity costs of $85.0 \mathrm{~m} €(592 €$ per ha and year). As a potential compensation every German household would need to have an average WTP of $2.3 €$. A $5 \%$ share of natural forest areas would cost $37 \mathrm{~m} €$ a year requiring a WTP of $1.0 €$ per household. These results underline the financial feasibility of large-scale protection in Central European PA like e.g. the German National Biodiversity Protection Strategy 2007 which requires that $5 \%$ of the German forest area respectively $10 \%$ of the state forest area should be devoted to biodiversity protection (BMU 2007).

However, it is surprising that the opportunity costs of PA did not become the focus of research in the German-speaking countries with their strong forestry tradition much earlier, the more as these opportunity costs are standard arguments against PA designations (MAYER 2013, 170).

\section{Cost-benefit analyses}

There are only a few more or less comprehensive cost-benefit analyses (CBA) of PA in the German-speaking countries (Tab. 3). That means that for the past ScHMID's $(2006,8 \mathrm{f}$.) observation holds true, that CBA were not applied in the designation processes of German PA and were even considered methodologically impractical (DiePolder 1997, 81; SCHERER/SCHUlTZ 1997). In contrast, for nearly all actual Austrian national parks CBA were used in the planning phase. It is only with the two youngest national park projects in Germany, the meanwhile cancelled Nationalpark Teutoburger Wald / Eggegebirge and the newly designated Nationalpark Schwarzwald, that more or less explicit CBA were undergone.

However, from a scientific perspective none of the existing studies with the exception of MAYER
(2013) is based on the TEV conception presented above (for a detailed critical discussion of these CBA studies see MAYER 2013, $172 \mathrm{f}$.). All in all the benefit-cost relation (BCR) in existing studies is either positive for the "PA" land use option (Nationalparks Oberösterreichische Kalkalpen, Schleswig-Holsteinisches Wattenmeer, Schwarzwald, Bayerischer Wald, for the regional and the national maximum scenarios) or more or less neutral (Nationalparks Donauauen and Teutoburger Wald/Eggegebirge, Schorfheide-Chorin Biosphere Reserve). Only very strict assumptions lead to a negative $B C R$ for PA (Nationalparks Donau-Auen and Bayerischer Wald for the national minimum scenario). These results underline the fact that PA designations are not in any case economically negative if the most important cost and benefit categories are considered.

\section{Overall results and further research needs}

We conclude the review of economic valuation of PA in German-speaking countries with the observation that significant work has already been accomplished during the last three decades. There is a lot of empirically well-founded evidence that PA are important attractions for nature-based tourism and that PA-induced tourism serves as a major tool for the regional development of peripheral and structural weak PA regions. However, most analyses to date fail to contrast the impact of PA tourism with their direct, indirect and opportunity costs, which exposes such studies to the criticism of a biased analysis and potentially weakens the argument in favor of parks. Furthermore, due to the lack of TEV studies of PA, the absolute and relative weight of tourism benefits among all ecosystem services is mostly unknown: Do tourism benefits constitute the tip of the iceberg or do they in fact make a major contribution? At the same time it would be worth contrasting the direct costs of PA (e. g. their annual budget) with their total societal benefits, which could be estimated for instance using the consumer surplus of the recreational value or the WTP for non-use values. The research question would be whether society's expenditures for PA are compensated by the monetarized appreciation of visitors and non-visitors.

The relatively limited number of comprehensive CBA of PA in German-speaking countries provides mostly positive answers to those questions 
as the BCR in most cases are positive or at least neutral from a PA perspective. Nevertheless, a stronger research focus on the recreational values of PA (measured with TCM), ecosystem service values (so far nearly completely neglected in PA valuation studies), intangible use values (infrastructure, image ...) and non-use values (only one study explicitly incorporated them) would likely even improve the standing of PA compared to their alternative land use options (intensive forestry or agriculture in most cases). Considering the general public, the contribution of PröbSTL-Haider/Haider (2014) points to the need for a representative survey dealing with the role of PA in tourism destination and recreational setting choice. How important are the PA labels when considering them not on-site but in the source markets and when incorporating other decisive factors like distance, time and cost constraints, recreational alternatives, preferences, activities, etc. leading to trade-offs in a choice experiment? This kind of research would certainly deepen the understanding of the attractiveness of PA as markers in the sense of LEIPER's (1990) seminal model and its application on PA (e. g. Wall Reinius / Fredman 2007). Additionally, also the analysis of non-tourism related use values of PA like the economic impact of park expenditures for staff, management and maintenance or the productive use values of forestry in buffer zones, for example, could fill existing knowledge gaps.

Considering the PA categories analyzed, the dominance of national parks is apparent, while biosphere reserves and (regional) nature parks are strongly underrepresented compared to their size and share of land area. Other PA categories like e. g. nature conservation areas (NSG), protected landscapes (LSG) or Austrian "Ruhegebiete" were not even included in the review. This is, however, also due to the fact that not even one valuation study about these PA categories is available. The same lack of actual valuation studies holds also true for Natura 2000 areas.

At least Getzner et al. (2002) modeled ex-ante the regional economic impact of several Austrian Natura 2000 areas like Karwendel, Verwall or Waldviertel and extrapolated that for all circa 150 Austrian Natura 2000 regions the set-up costs would amount to more than $70 \mathrm{~m} €$ leading to an economic impact of $29.1 \mathrm{~m} €$ while the current expenses of about $10.9 \mathrm{~m} € /$ year would induce an economic impact of $7.3 \mathrm{~m} € /$ year. They conclude that the establishment of the $\mathrm{Na}$ - tura 2000 PA system would most likely lead to limited regional economic impact provoked by tourism growth and related demand increases for regional products while the opportunity costs for the primary sector would be compensated for the most part. They also show that especially for the less prominent PA categories with a lower effect on tourism demand the state expenses are crucial for the regional economic impact. The money spent on nature conservation areas is not lost at all but constitutes an income transfer for the mostly peripheral PA regions.

From an economic geography perspective, it is noteworthy that so far only MAYER $(2013,2014)$ tried to analyze the benefits and costs of a PA on different spatial scales. He revealed that while the BCR of the Nationalpark Bayerischer Wald is positive only in half of the national economy scenarios, all regional economic scenarios show positive results for the park which underlines its important role in regional development. Hence, as this question of the spatially unequal distribution of protected areas' benefits and costs can be considered as crucial for society's debate about future PA designations, there is still a lot of research to be done until generalizable results will be available. Of course, the geographical scope of this review is not satisfying. An extension to Western, Northern, Eastern and Southern Europe would be of great interest.

A major difficulty in assessing the economic values of PA in the German-speaking countries is the often poor comparability of the results due to differing methodological approaches - a prominent example are the economic impact analyses of PA in Switzerland (KÜPFER 2000; BACKHAUS et al. 2013) and Germany (Јов et al.) -, input data sources/availability/quality, (theoretical) assumptions and the delimitation of survey areas (Mose 2007).

These problems lead to the need for the development and implementation of a standardized socio-economic monitoring system for PA throughout Europe. On the national level, the economic impact studies in German national parks and biosphere reserves by JоB et al. could serve as an example (WOLTERING 2012) as well as the advanced PA monitoring work in Finland (KAJALA et al. 2007).

However, it should not be forgotten that PA are not primarily designated for economic reasons but priority should be given to biological con- 
servation and the preservation of cultural landscapes. Therefore, the focus should be set on quality instead of quantity (also in terms of tourism development, visitor numbers, experiences and expenditures etc.). This also holds true for PA established in order to foster regional development: PA are no panacea for structurally weak regions if there are not any better ideas of how to develop such regions or gain subsidies. Additionally, PA should not be created just for political reasons like for instance if a territorial entity does not yet have a national park (see also JoB 2010; MAYER 2013, 472, 489 f.).

Notwithstanding the considerable research progress summed up in this review, there would appear to be quite some work required to achieve an integration of contemporary mainstream economic geography into PA research. Potential approaches could be for example:

- Examining the nexus between PA and (tourism) entrepreneurs/businesses: Do they cooperate? If yes, to what extent, for which motivations and what is the outcome? Do businesses in PA regions form networks among each other and their respective PA? Do they develop mutual trust despite the often strained relations between PA and local populations (see BECKEN/JoB 2014)?

- The relation between PA and the path dependency of regional economic development of their surroundings: Are PA designated because of a lack of better economic development alternatives (see RUNTE 1977) and therefore continue along a marginalized, externally driven development path? Or could they also be regarded as innovative institutions fostering regional economic development by initiating the formation of networks, attracting new actors and educated labor forces (directly employed or by means of amenity migration), improving the region's image and thus becoming the focal point of a potential learning region? (see Mose/Weixlbaumer 2003)

In a wider context of a broader human geography of PA three further points would be of special interest:

- How representative are PA systems in terms of biomes and ecosystems and what are their contributions to ecosystem services? (For instance, in Germany mountain spruce forests are overrepresented in the PA system
(BLE 2014) as is the case in the Alps with the "worthless" high alpine ranges, following RUNTE's thesis (1977).)

- How do neighboring people, the public in general and decision makers perceive the new and unfamiliar landscape and ecosystem consequences of PA like a high proportion of dead wood in forests, the habitat function for returning predators like wolves or mass propagation of insects like bark beetles? (acceptance research; see DEPRAZ 2011; LASLAZ 2011)

- How do PA really influence the regional identity of European peripheral regions (image effects of PA)?

\section{Outline of this special issue}

The research topics of the economic geography of PA are of course not limited to the mere economic valuation of PA. However, despite the knowledge gaps mentioned the review for the German-speaking countries shows that the valuation of PA is an important and still growing field of research for applied economic geography which provides considerable input and relevant advice for PA and tourism managers and other practitioners (JOB et al. 2013b). After the presentation of the state of the art, the other articles of this special issue each focus on further related research problems.

Not only was the cost-side of PA overshadowed by the focus on PA benefits for a long time, but also the issue of PA financing has been mostly neglected so far. Thus SCHRÖTER-SCHLAACK et al. (2014) deal with the financing of PA and discuss whether intergovernmental fiscal transfers would be a suitable way to strengthen local conservation efforts. The authors rely on empirical experiences of this inclusion of ecological indicators in the redistribution of public revenues in Portugal and France. Design features which are critical for the success of fiscal transfers against the ongoing loss of biodiversity outside and partly in PA too, are identified. Based on that, recommendations for the improvement of existing or the introduction of new ecological fiscal transfer schemes are given.

BYSTRÖM/MÜLLER (2014) chose the extreme European periphery of Swedish Lapland to analyze the impacts of national parks on the tourism labor market which serves not only as an impor- 
tant indicator for the effects of PA on regional development, but also as a different methodological approach to assess these effects. The paper shows that the assumption that nature protection through PA promotes positive economic development with the help of nature-based tourism is not applicable in the rural periphery of Swedish Lapland.

The contribution of MÜLLER (2014) in contrast widens the geographical and temporal scope to a long-term political ecology perspective of PA governance and philosophy in Russia, which have undergone significant changes in the postSoviet era in terms of shifting the focus from nature conservation to a stronger commercial approach. This article underlines the fact that the economic geography of PA also encompasses issues of governance and political ecology as far as they are related to use or non-use of PA. The paper concludes that the neoliberal impetus of introducing market principles into PA management in Russia is in danger of going off course: instead of making the market work for conservation, it makes conservation work for the market.

PröBSTL-HAider/Haider (2014) analyze the role of PA for destination choice in the European Alps based on the analyses of the most relevant types of PA and their supply for tourism development and a representative online survey of the German population interested in holidays in the alpine area using a choice experiment. Results suggest that only tourists who are really familiar with the Alps are able to distinguish the different PA categories, which are not as relevant for destination choice as suggested by the literature. However, as nature experience offers by all types of PA are of high relevance within the destination choice this aspect should be used and communicated in destination branding based on PA.

As biosphere reserves aim at providing a holistic example of sustainable development, tourism development should not always be at the center of their interest, but also a sustainable regional economic development through the intensification of regional value chains of regionally based food processing, for example. In order to evaluate the effectiveness of a regional labeling scheme aimed at strengthening these regional value chains the contribution of Kraus et al. (2014) analyzes businesses of the Dachmarke Rhön and a control group in the German Biosphere Reserve Rhön based on face-toface interviews with managers. Results suggest that the members of the Dachmarke Rhön are putting more emphasis on regional buying and the relationship to the supplier, which leads to higher expenses for supplies and a lower direct regional economic impact. However, these expenses stay within the region to a greater proportion and benefit not only trade but also regional agricultural and processing businesses. Thus indirect regional economic effects are maximized, fostering multifunctionality at the same time. The Dachmarke Rhön can thus be seen as an adequate tool for promoting sustainable economic development in the context of biosphere reserve management in Germany.

\section{Acknowledgments}

The authors would like to thank the contributors to this special issue and also Hazel Schauss for language editing and proof reading.

\section{References}

Akademie für Umweltforschung und -bildung in Europa (AUBE) e. V. (Hrsg.) (2003): Nationalparke als Wirtschaftsfaktor für eine nachhaltige Regionalentwicklung. Ergebnisse der Befragung der Nationalparke in Deutschland und Erwartungen für einen potentiellen Nationalpark Senne. Bielefeld.

Archer, B. / Fletcher, J.E. (1996): The economic impact of tourism in the Seychelles. In: Annals of Tourism Research, (23)1, 32-47.

Arnberger, A. / Eder, R. / Allex, B. / Sterl, P. / Burns, R.C. (2012): Relationships between national-park affinity and attitudes towards protected area management of visitors to the Gesaeuse National Park, Austria. In: Forest Policy and Economics, 19, 48-55.

BaAske, W. / Reiterer, F. / Sulzbacher, R. (1998): KostenNutzen-Analyse Nationalpark OÖ Kalkalpen. Schlierbach.

BAChleitneR, R./WeichBold, M. (2004): Nationalpark sucht Gäste! Naturspektakel oder Nächtigungsdebakel? In: Tourismus Journal, (8)2, 223-232.

Backhaus, N. / Buser, C. / Butticaz, M. / Jorio, D. / Speich, M. (2013): Wirtschaftliche Auswirkungen des Sommertourismus im UNESCO Biosphärenreservat Val Müstair Parc Naziunal. Zürich. (Schriftenreihe Humangeographie 27).

Balmford, A. / Bruner, A. / CoOper, P. / Costanza, R. / FArBer, S. / Green, R. E. / Jenkins, M. / JefFeriss, P. / Jessamy, V. / Madden, J. / Munro, K. / Myers, N. / NAeEM, S. / PAAvola, J. / Rayment, M. / Rosendo, S. / Roughgarden, J. / TRUMPER, K. / TURNER, R. K. (2002): Economic reasons for conserving wild nature. In: Science, (297)5583, 950-953.

BArbier, E. B. / Acreman, M. / KNowler, D. (1997): Economic valuation of wetlands. A guide for policy makers and planners. Gland. 
BARBIER, E. B. (1991): Environmental degradation in the Third World. In: Pearce, D. (Ed.): Blueprint 2. Greening the world economy. London, 75-108.

BAtHeLt, H. / GLÜCKLER, J. ( $\left.{ }^{3} 2012\right)$ : Wirtschaftsgeographie. Stuttgart.

Becken, S. / Job, H. (2014): Protected areas in an era of global change. In: Journal of Sustainable Tourism, (22)4, 507-527.

Beckmann, O. (2003). Die Akzeptanz des Nationalparks Niedersächsisches Wattenmeer bei der einheimischen Bevölkerung. Frankfurt am Main.

Bergen, V./LöWenstein, W. (1995 [1992]): Die monetäre Bewertung der Fernerholung im Südharz. In: Bergen, V./ Löwenstein, W. / Pfister, G. (Hrsg.): Studien zur monetären Bewertung von externen Effekten der Forst- und Holzwirtschaft. Frankfurt am Main, 1-58. (Schriften zur Forstökonomie 2).

BfN (Bundesamt für Naturschutz) (Hrsg.) (2014): Naturschutzgebiete. Internet: http://www.bfn.de/0308_nsg.html, $<30.6 .2014>$

BfN (Bundesamt für Naturschutz) (Hrsg.) (2012): Daten zur Natur 2012. Münster.

Blaikie, P. / Jeanrenaud, S. (1997): Biodiversity and human welfare. In: Ghimire, K. B./Pimbert, M.P. (Eds.): Social change and conservation. Environmental politics and impacts of national parks and protected areas. London, 46-70.

BLE (Bundesanstalt für Landwirtschaft und Ernährung) (Hrsg.) (2014): Datenbank Naturwaldreservate in Deutschland. Übersichtskarte. Internet: http://www.naturwaelder. de/index.php?tpl=karte, 21.6.2014.

Blum, A. (1999): Regionalwirtschaftliche Bedeutung der Forstwirtschaft. Freiburg im Breisgau. (Schriften aus dem Institut für Forstökonomie der Universität Freiburg 10).

BMU (Bundesministerium für Umwelt, Naturschutz und Reaktorsicherheit) (Hrsg.) (2007): Nationale Strategie zur biologischen Vielfalt. Berlin. Internet: http://www.bmu.de/ files/pdfs/allgemein/application/pdf/broschuere_biolog vielfalt_strategie_bf.pdf, 20.6.2014.

Bodenhöfer, H.-J. / Bliem, M. G. / Klinglmair, A. (2009): Ökonomische Wirkungsanalyse des Nationalparks Hohe Tauern. Endbericht. Klagenfurt. Internet: http://www.lawine.ktn.gv.at/198047p_DE-, 20.6.2014.

Brookshire, D. S. / Eubanks, L. S. / RANDALL, A. (1983): Estimating option prices and existence values for wildlife resources. In: Land Economics, (59)1, 1-15.

ButLer, R.W. (1980): The concept of a tourist area cycle of evolution. Implications for management of resources. In: The Canadian Geographer, (24)1, 5-12.

ByströM, J./ MÜLleR, D. K. (2014): Tourism labor market impacts of national parks. The case of Swedish Lapland. In: Zeitschrift für Wirtschaftsgeographie, (58)2-3, 115-126.

CARLSEN, J. (1997): Economic evaluation of recreation and tourism in natural areas. A case study in New South Wales, Australia. In: Tourism Economics, (3)3, 227-239.

ConNer, N. (2007): Economic impacts of parks on surrounding communities. Findings from New South Wales. In: Bushell, R. / Eagles, P. (Eds.): Tourism and protected areas. Benefits beyond boundaries. The Vth IUCN World Parks Congress. Oxfordshire/Cambridge, 210-230.
DepraZ, S. (2011): Les territoires de nature protégée, de la théorie participative aux pratiques de bonne gouvernance. In: Bulletin de 1'Association de Géographes Français, (88)4, 365-374.

Destatis (Statistisches Bundesamt) (Hrsg.) (2013): Statistisches Jahrbuch 2013. Wiesbaden.

Diepolder, U. (1997): Zustand der deutschen Nationalparke im Hinblick auf die Anforderungen der IUCN. München.

Dixon, J.A. / SHERMAN, P. B. (1990): Economics of protected areas. A new look at benefits and costs. Washington, D.C. Dixon, J.A. / Sherman, P. B. (1991): Economics of protected areas. In: Ambio, (20)2, 68-74.

DudLey, N. (Ed.) (2008): IUCN guidelines for applying protected area management categories. Gland. (Internet: http://cmsdata.iucn.org/downloads/guidelines_for_applying protected_area_management_categories.pdf, 17. $\overline{6} .2014)$.

Edwards, P. J./ABIVARdi, C. (1998): The value of biodiversity: Where ecology and economy blend. In: Biological Conservation, (83)3, 239-246.

Elsasser, H. / Seiler, C. / Scheurer, T. (1995): The regional economic impacts of the Swiss National Park. In: Mountain Research and Development, (15)1, 77-80.

Elsasser, P. (1996): Der Erholungswert des Waldes. Monetäre Bewertung der Erholungsleistung ausgewählter Wälder in Deutschland. Frankfurt am Main. (Schriften zur Forstökonomie 11).

FARBER, S. / Costanza, R. / Wilson, M.A. (2002): Economic and ecological concepts for valuing ecosystem services. In: Ecological Economics, (41)3, 375-392.

Feige, M. / Harrer, B. / Möller, A. / Piech, I. / TriebswetTER, U. (1995): Ökosystemforschung Schleswig-Holsteinisches Wattenmeer. Projektberichte Sozioökonomie. Teil C: Das anthropogene System des Nationalparks. München.

FleischHacker, V./PAuer, P. (2001): Nationalparks und Tourismus in Österreich 2001. Stellung, Struktur und Tendenzen der Tourismuswirtschaft sowie Perspektiven der Tourismusnutzung in den Nationalparkregionen. Tulln an der Donau.

FLÜCKIGER, V. (2000): Öffentliche Güter - offene Fragen. Die Theorie der öffentlichen Güter in aktuellen Diskussionen der Raumordnungspolitik. Zürich.

GETZNER, M. (2010): Impacts of protected areas on regional development. The case of the Hohe Tauern national park (Austria). In: Journal of Sustainable Economy, (2)4, 419441.

GETZNER, M. (2008): Impacts of national parks on tourist flows. A case study from a prominent alpine national park. In: Economia delle Fonti di Energia e dell'Ambiente, (60)3, 205-223.

GetZneR, M. (2003): The economic impact of national parks. The perception of key actors in Austrian national parks. In: International Journal of Sustainable Development, (6)2, 183-202.

Getzner, M. / Jost, S. / Jungmeier, M. (2002): Naturschutz und Regionalwirtschaft. Regionalwirtschaftliche Auswirkungen von Natura 2000-Gebieten in Österreich. Frankfurt am Main.

VON HAAREN, C. (Ed.) (2014): Naturkapital Deutschland TEEB DE: Ökosystemleistungen und Entwicklung ländlicher Räume. (in Vorbereitung). 
HACKL, F. (1997): Contingent Valuation als Instrument zur ökonomischen Bewertung der Landschaft. Frankfurt am Main.

HAMPICKE, U. (1996): Volkswirtschaftliche Beurteilung und Bewertung von Großschutzgebieten. In: Forstwirtschaftliche Fakultät der Universität München, Bayerische Landesanstalt für Wald und Forstwirtschaft (Hrsg.): Großschutzgebiete. Ökonomische und politische Aspekte. 26. Kolloquium der Lehrstühle für Forstpolitik und Forstliche Wirtschaftslehre der Ludwig-Maximilians-Universität München. München, 19-43. (Forstliche Forschungsberichte München 156).

Hanley, N. / Barbier, E. B. (2009): Pricing nature. Costbenefit analysis and environmental policy. Cheltenham.

Hannemann, T./Job, H. (2003): Destination ,Deutsche Nationalparke' als touristische Marke. In: Tourism Review, (58)2, 6-17.

Heintel, M. / Weixlbaumer, N. (2009): Die regionalökonomische Bedeutung des österreichischen Naturparktourismus. Das Beispiel Burgenland. In: Natur und Landschaft, (84)7, 315-321.

HJERPE, E.E. / KIM, Y.-S. (2007): Regional economic impacts of Grand Canyon river runners. In: Journal of Environmental Management, (85)1, 137-149.

ITR (Institut für touristische Raumplanung) (Ed.) (1993): Expertise zur Machbarkeitsstudie Nationalpark Thayatal Beurteilung der tourismusrelevanten Aussagen. Tulln an der Donau.

Job, H. / Woltering, M. / Schamel, J. / Merlin, C. (2014a): Regionalökonomische Effekte des Nationalparks Schleswig-Holsteinisches Wattenmeer. Würzburg. (unpublished project report).

Job, H. / Woltering, M. / Schamel, J. / Merlin, C. (2014b): Regionalökonomische Effekte des Nationalparks Harz. Würzburg. (unpublished project report).

Job, H. / Kraus, F. / Merlin, C. / Woltering, M. (2013a): Wirtschaftliche Effekte des Tourismus in Biosphärenreservaten Deutschlands. Bonn-Bad Godesberg. (Naturschutz und Biologische Vielfalt 134).

Job, H. / BeCKen, S. / SACHER, P. (2013b): Wie viel Natur darf sein? Schutzgebietskonzepte im Wandel der Zeit. In: Standort, (37)4, 204-210.

JoB, H. / MAYER, M. (2012): Forstwirtschaft versus Waldnaturschutz: Regionalwirtschaftliche Opportunitätskosten des Nationalparks Bayerischer Wald. In: Allgemeine Forstund Jagdzeitschrift, (183)7/8, 129-144.

Job, H. / Woltering, M. / Kraus, F. (2012): Aktuelle und potenzielle regionalökonomische Effekte des Biosphärenreservates Vessertal-Thüringer Wald. Würzburg. (unpublished project report).

JoB, H. (2010): Welche Nationalparke braucht Deutschland? In: Raumforschung und Raumordnung, (68)2, 75-89.

Job, H. / Woltering, M. / Merlin, C. (2010): Regionalwirtschaftliche Effekte des Tourismus im Nationalpark Sächsische Schweiz - Kurzfassung. In: Staatsbetrieb Sachsenforst, Amt für Großschutzgebiete Nationalparkverwaltung Sächsische Schweiz (Hrsg.): Der Nationalpark Sächsische Schweiz als regionaler Wirtschaftsfaktor. Bad Schandau, 4-33.
Job, H./ Woltering, M./ Harrer, B. (2009a): Regionalökonomische Effekte des Tourismus in deutschen Nationalparken. Bonn-Bad Godesberg. (Naturschutz und Biologische Vielfalt 76).

Job, H./ARnegGer, J./ Woltering, M. (2009b): Ex-ante Evaluation der regionalökonomischen Wirkungen der Einrichtung eines Nationalparks in der Region Lieberose. Würzburg. (unpublished project report).

Job, H. / Harrer, B. / Metzler, D. / Hajizadeh-Alamdary, D. (2005): Ökonomische Effekte von Großschutzgebieten. Untersuchung der Bedeutung von Großschutzgebieten für den Tourismus und die wirtschaftliche Entwicklung der Region Bonn-Bad Godesberg. (BfN-Skripten 135).

JoB, H. / METZLeR, D. (2005): Regionalökonomische Effekte von Großschutzgebieten. In: Natur und Landschaft, (80)11, 465-471.

Job, H. / Metzler, D. / Vogt, L. (2003): Inwertsetzung alpiner Nationalparks. Eine regionalwirtschaftliche Analyse des Tourismus im Alpenpark Berchtesgaden. Kallmünz/Regensburg. (Münchner Studien zur Sozial- und Wirtschaftsgeographie 43).

Joв, H. (1996): Großschutzgebiete und ihre Akzeptanz bei Einheimischen. Das Beispiel der Nationalparke im Harz. In: Geographische Rundschau, (48)3, 159-165.

JungmeIER, M. / Velik, I. (Hrsg.) (1999): Machbarkeitsstudie Nationalpark Gesäuse, Endbericht. Klagenfurt.

Kajala, L. / AlmiK, A. / DAhl, R. / DikŠAité, L. / ERKKonen, J. / Fredman, P. / Jensen, F. S. / Karoles, K. / SievÄnen, T. / Skov-Petersen, H./Vistad, O. I. / Wallsten, P. (2007): Visitor monitoring in nature areas - a manual based on experiences from the Nordic and Baltic countries. Tema Nord 2007:534. Internet: http://www.naturvardsverket.se/Documents/publikationer/620-1258-4.pdf?pid=2661, 19.6.2014.

Ketterer, L. / Siegrist, D. (2009): Touristische Potenziale der Österreichischen Naturparke. Rapperswil. (Schriftenreihe des Institut für Landschaft und Freiraum 5; Internet: http://www.naturparke.at/downloads/studie_touristische potenziale_der_oesterr_naturparke.pdf, 17.6.2014).

KLeINHENZ, G. (1982): Fremdenverkehr und Nationalpark. Die fremdenverkehrswirtschaftliche Bedeutung des Nationalparks Bayerischer Wald. Grafenau.

Kletzan, D. / KratenA, K. (1999): Evaluierung der ökonomischen Effekte von Nationalparks. Wien.

KNAUS, F. (2012): Bedeutung, Charakteristiken und wirtschaftliche Auswirkungen des Sommertourismus in der UNESCO Biosphäre Entlebuch. Schüpfheim.

KNOKE, T./Moog, M. (2005): Timber harvesting versus forest reserves - producer prices for open-use areas in German beech forests (Fagus sylvatica L.). In: Ecological Economics, (52)1, 97-110.

KoRFF, K. (2004a): Die regionalwirtschaftliche Bedeutung des nationalparkorientierten Tagestourismus am SchleswigHolsteinischen Wattenmeer. Unveröffentlichter Projektbericht. Garding.

KorfF, K. (2004b): Die regionalwirtschaftliche Bedeutung des nationalparkorientierten Übernachtungstourismus am Schleswig-Holsteinischen Wattenmeer. Garding. (unpublished diploma thesis TU Dresden). 
Kosz, M. (1996): Valuing riverside wetlands: the case of the 'Donau-Auen' national park. In: Ecological Economics, (16)2, 109-127.

Kraus, F. / Merlin, C. / Job, H. (2014): Biosphere Reserves and their contribution to sustainable development. A valuechain analysis in the Rhön Biosphere Reserve. In: Zeitschrift für Wirtschaftsgeographie, (58)2-3, 164-180.

Krutilla, J. V. / Fisher, A. C. (1975): The economics of natural environments. Studies in the valuation of commodity and amenity resources. Baltimore.

KÜPFER, I. (2000): Die regionalwirtschaftliche Bedeutung des Nationalparktourismus. untersucht am Beispiel des Schweizerischen Nationalparks. Zernez. (NationalparkForschung in der Schweiz 90).

LASlaz, L. (2011): Produisons du conflit, il restera toujours de l'acceptation: Tensions et concertations autour des chartes des parcs nationaux français. In: Bulletin de l'Association de Géographes Français, (88)4, 387-402.

Lehar, G. / Hausberger, K. / Fuchs, L. (2004): Besucherzählung, Wertschöpfungs- und Motiverhebung im Nationalpark Hohe Tauern und im Naturpark Rieserferner-Ahrn. Innsbruck.

LEIPER, N. (1990): Tourist attraction systems. In: Annals of Tourism Research, (17)3, 367-384.

Liebecke, R. / Wagner, K. / SudA, M. (2009): Akzeptanzforschung zu Nationalparks. Ein empirisches Beispiel aus dem Nationalpark Bayerischer Wald. In: Natur und Landschaft, (84)11, 502-508.

LÖWEnsteIn, W. (1994): Die Reisekostenmethode und die bedingte Bewertungsmethode als Instrumente zur monetären Bewertung der Erholungsfunktion des Waldes. Ein ökonomischer und ökonometrischer Vergleich. Frankfurt am Main. (Schriften zur Forstökonomie 6).

LutTMAnN, V. / SchröDER, H. (1995): Monetäre Bewertung der Fernerholung im Naturschutzgebiet Lüneburger Heide. Frankfurt am Main. (Schriften zur Forstökonomie 10).

Mayer, M. (2014): Can nature-based tourism benefits compensate for the costs of national parks? A study of the Bavarian Forest National Park, Germany. In: Journal of Sustainable Tourism, (22)4, 561-583.

Mayer, M. (2013): Kosten und Nutzen des Nationalparks Bayerischer Wald. Eine ökonomische Bewertung unter Berücksichtigung von Tourismus und Forstwirtschaft. München.

Mayer, M. / Müller, M./ Woltering, M. / ArnegGer, J./ JoB, H. (2010): The economic impact of tourism in six German national parks. In: Landscape and Urban Planning, (97)2, 73-82.

Mayer, M. / Wasem, K. / Gehring, K. / PütZ, M. / RoscheWITZ, A./SIEGRIst, D. (2009): Wirtschaftliche Bedeutung des naturnahen Tourismus im Simmental und Diemtigtal - Regionalökonomische Effekte und Erfolgsfaktoren. Birmensdorf/Rapperswil.

MAYer, M. / Woltering, M. (2008): Angebotsseitige Analyse des Tourismus in der Nationalparkregion Bayerischer Wald. In: Job, H. (Hrsg.): Die Destination Nationalpark Bayerischer Wald als regionaler Wirtschaftsfaktor. Grafenau, 66-99.

Meyerhoff, J. (1999): Ökonomische Bewertung ökologischer Leistungen. Berlin.
MoISEY, R. N. (2002): The economics of tourism in national parks and protected areas. In: Eagles, P. F. J. / McCool, S. F. (Eds.): Tourism in national parks and protected areas. Planning and management. New York, 235-253.

MosE, I. (2007) (Ed.): Protected areas and regional development in Europe. Towards a new model for the 21 st century. Aldershot.

Mose, I. / Weixlbaumer, N. (2003): Großschutzgebiete als Motoren einer nachhaltigen Regionalentwicklung? Erfahrungen mit ausgewählten Schutzgebieten in Europa. In: Hammer, T. (Hrsg.): Großschutzgebiete. Instrumente nachhaltiger Entwicklung. München, 35-95.

MülLeR, M. (2014): From sacred cow to cash cow: the shifting political ecologies of protected areas in Russia. In: Zeitschrift für Wirtschaftsgeographie, (58)2-3, 127-143.

MüLLER, M. (2011): How natural disturbance triggers political conflict. Bark beetles and the meaning of landscape in the Bavarian Forest. In: Global Environmental Change, (21)3, 935-946.

MunAsinghe, M. (1992): Biodiversity protection policy. Environmental valuation and distribution issues. In: Ambio, (21)3, 227-236.

Nationalparkplanung Thayatal-Betriebsgesellschaft Marchfeldkanal, Ö.-R. G.m.b.H. (Hrsg.) (1995): Nationalpark Thayatal Österreich. Abschätzung der regionalwirtschaftlichen Effekte. Wien.

Pascual, U. / Muradian, R. / Brander, L. / Gomez-Baggethun, E. / MARTin-Lopez, B. / Verma, M. / ARMSWORTH, P./ Christie, M. / Cornelissen, H. / Eppink, F. / Farley, J./ Loomis, J.B. / Pearson, L. / Perrings, C.A. / Polasky, S. (2010): Chapter 5: The economics of valuing ecosystem services and biodiversity. In: Kumar, P. (Ed.): The economics of ecosystems and biodiversity. Ecological and Economic Foundation. Bonn, 183-256.

Pearce, D. W. / Moran, D. (1994): The economic value of biodiversity. London.

Pearce, D. W. / Turner, R. K. (1990): Economics of natural resources and the environment. Baltimore.

PricewaterhouseCoopers/ö:konzept (Hrsg.) (2013): Gutachten zum potenziellen Nationalpark im Nordschwarzwald. Gutachten zu Händen des Ministeriums für Ländlichen Raum und Verbraucherschutz des Landes BadenWürttemberg. Berlin. (Internet: http://schwarzwald-nationalpark.de/fileadmin/website pictures/Gutachten/Gesamtgutachten_final.pdf, 17.6.2014.

Pröbstl-Haider, U. / Haider, W. (2014): The role of protected areas for destination choice in the European Alps. In: Zeitschrift für Wirtschaftsgeographie, (58)2-3, 144-163.

Pröbstl-Haider, U./ Wirth, V. / Haider, W. (2014): Wie viel „Natur“ suchen deutsche Urlauberinnen und Urlauber in den Alpen? Eine Quellgebietsstudie bezogen auf den Sommertourismus. In: Natur und Landschaft, (89)1, 26-32.

Randall, A. / Stoll, J. (1983): Existence values in a total valuation framework. In: Row, R. D. / Chestnut, L. G. (Eds.): Managing air quality and scenic resources at national parks and wilderness areas. Boulder, 265-274.

Rein, H./ Schneider, N. (2009): Die Wertschöpfung des Tourismus im Nationalpark Unteres Odertal. Schwedt. (unpublished report). 
RENTSCH, G. (1988): Die Akzeptanz eines Schutzgebietes untersucht am Beispiel der Einstellung der lokalen Bevölkerung zum Nationalpark Bayerischer Wald. Kallmünz/Regensburg. (Münchener Geographische Hefte 57).

Roland Berger Strategy Consultants (Hrsg.) (2010): Konzeption und Wirtschaftlichkeit des Nationalparks Teutoburger Wald/Eggegebirge. Zusammenfassung der Ergebnisse des Gutachtens. Hamburg. (Internet: http://www.natio nalpark-teutoburgerwald-eggegebirge.de/fileadmin/user upload/Downloads/Zusammenfassung_Roland_Berger_ Gutachten_zum_Nationalpark_Teutoburger_Wald.pdf, 17.6.2014).

Rommel, K. (1998): Methodik umweltökonomischer Bewertungsverfahren. Kosten und Nutzen des Biosphärenreservates Schorfheide-Chorin. Regensburg. (Volkswirtschaftliche Schriften Univ. Kaiserslautern 16).

Rothgang, M. (1997): Ökonomische Perspektiven des Naturschutzes. Analyse naturschutzpolitischer Ansätze im Hinblick auf das Zusammenwirken von ökologischen Begrenzungen, institutionellen Strukturen und ökonomischen Erfordernissen. Berlin. (Abhandlungen zur Nationalökonomie 8).

RucK, C. (1990): Die ökonomischen Effekte von Nationalparks in Entwicklungsländern. Augsburg.

RuNTE, A. (1977): The national park idea. Origins and paradox of the American experience. In: Journal of Forest History, (21)2, 64-75.

VON RuschKowski, E. (2010): Ursachen und Lösungsansätze für Akzeptanzprobleme von Großschutzgebieten, am Beispiel von zwei Fallstudien im Nationalpark Harz und im Yosemite National Park. Stuttgart.

RÜTTER, H. / GuHL, D. / MüLlER, H. (1996): Wertschöpfer Tourismus. Ein Leitfaden zur Berechnung der touristischen Wertschöpfung und Beschäftigung in 13 pragmatischen Schritten. Rüschlikon/Bern.

Rütter, H. / Müller, H. / GuHl, D. / Stettler, J. (1995): Tourismus im Kanton Bern. Wertschöpfungsstudie. Bern.

SCHERER, R. / SchULTZ, B. (1997): Regionalökonomische Auswirkungen von Großschutzgebieten. Eine modellhafte Anwendung der Inzidenzanalyse am Beispiel des Biosphärenreservates Oberlausitzer Heide- und Teichlandschaft. Freiburg im Breisgau. (Internet: http://www.eures.de/de/ publikationen/download/DP-61.pdf, 17.6.2014).

SCheurer, T./SteIger, C. (1993): Der Schweizerische Nationalpark (Unterengadin). Sein Nutzen und seine regionalwirtschaftliche Bedeutung. Ein Werkstattbericht. In: Dorninger, G. / Weixlbaumer, N. (Hrsg.): ,Aufstand für die Natur?‘. Problemwahrnehmung, Naturschutz und Regionalentwicklung. Gebietsschutzstrategien in ausgewählten Regionen Europas. Wien, 113-148.

Schmid, J. (2006): Regionalökonomische Wirkungen von Großschutzgebieten. Eine empirische Studie zu den Nationalparken in Deutschland. Hamburg. (Schriftenreihe Agraria 31).

SCHÖNBÄCK, W. / Kosz, M. / MAdREITER, T. (1997): Nationalpark Donauauen. Kosten-Nutzen-Analyse. Wien.

SCHRÖTER-SchlaAcK, C. / Ring, I. / KoEllner, T. / SANTOS, R. / Antunes, P. / Clemente, P. / Mathevet, R. / Borie, M. /
GroDZIŃSKA-JURCZAK, M. (2014): Intergovernmental fiscal transfers to support local conservation action in Europe. In: Zeitschrift für Wirtschaftsgeographie, (58)2-3, 98-114.

Siegrist, D. / Aufdereggen, M. / Lintzmeyer, F. / Spiess, H. (2006): Ökonomische Analyse von Regionalen Naturpark-Projekten im Kanton Bern. Rapperswil/Winterthur. (Internet: http://www.jgk.be.ch/jgk/de/index/raumplanung/ raumplanung/kantonale_raumplanung/paerke/grundlagen. assetref/content/dam/documents/JGK/AGR/de/Raumplanung/agr kpl studie p\%C3\%A4rke siegrist 2006 de.pdf, 17.6.2014).

STERN, M. (2008): The power of trust. Toward a theory of local opposition to neighboring protected areas. In: Society and Natural Resources, (21)10, 859-875.

SToLl, S. (1999): Akzeptanzprobleme bei der Ausweisung von Großschutzgebieten. Ursachenanalyse und Ansätze zu Handlungsstrategien. Frankfurt am Main.

TRIMBORN, R. (2006): Nationalpark Schleswig-Holsteinisches Wattenmeer als regionaler Wirtschaftsfaktor. Internet: http://www.inspektour.de/download/Nationalpark_Schleswig-Holsteinisches_Wattenmeer_als_regionaler_Wirtschaftsfaktor_Trimborn_061121.pdf, 17.6.2014.

Turner, R. K. / PaAvola, J. / CoOper, P. / Farber, S. / JesSAMY, V./GEORgIOU, S. (2003): Valuing nature. Lessons learned and future research directions. In: Ecological Economics, (46)3, 493-510.

Wall Reinius, S. / Fredman, P. (2007): Protected areas as attractions. In: Annals of Tourism Research, (34)4, 839854.

Walsh, R. G. / Loomis, J. B. / Gillman, R.A. (1984): Valuing option, existence, and bequest demands for wilderness. In: Land Economics, (60)1, 14-29.

WCPA (World Commission on Protected Areas) (Ed.) (1998): Economic values of protected areas. Guidelines for protected area managers. Gland. (Internet: http://cmsdata. iucn.org/downloads/pag_002.pdf, 17.6.2014).

WDPA (World Database on Protected Areas) (Ed.) (2012): Statistics. Internet: http://www.wdpa.org/Statistics.aspx, 28.3.2012.

WeisBrod, B.A. (1964): Collective-consumption services of individual-consumption goods. In: The Quarterly Journal of Economics, (78)3, 471-477.

Weixlbaumer, N. / Gamper, C. / Gruber, K. (2007): Naturparke Burgenland. Bedeutung der Naturparke Burgenlands für den Tourismus und die wirtschaftliche Entwicklung der Region. Wien. (Internet: http://www.rmb.co.at/media/ file/263_STUDIE_BGLD_finalversion.pdf, 17.6.2014).

Wells, M.P. (1992): Biodiversity conservation, affluence and poverty. Mismatched costs and benefits and efforts to remedy them. In: Ambio, (21)3, 237-243.

WOLTERING, M. (2012): Tourismus und Regionalentwicklung in deutschen Nationalparken. Regionalwirtschaftliche Wirkungsanalyse des Tourismus als Schwerpunkt eines sozioökonomischen Monitoringsystems. Würzburg. (Würzburger Geographische Arbeiten 108; Internet: http:// opus.bibliothek.uni-wuerzburg.de/volltexte/2012/7189/pdf/ DISS_WOLTERING.pdf, 17.6.2014). 